\title{
Corporate Culture and the Tournament Hypothesis
}

\author{
Neslihan Ozkan ${ }^{1}$ \\ School of Economics, Finance and Management \\ University of Bristol, UK \\ Oleksandr Talavera ${ }^{2}$ \\ School of Economics \\ University of East Anglia, UK \\ Anna Zalewska ${ }^{3}$ \\ School of Management, University of Bath, UK \\ CMPO, University of Bristol, UK
}

September 22, 2010

\begin{abstract}
The empirical literature on the effect of dispersion of executive remuneration (i.e., the intensity of a tournament structure) on the comparative performance of companies is mixed. Studies on US data tend to find strong positive effects but non-US studies tend to fail to find an effect. This suggests that tournaments are likely to be more effective in some situations than others. Using UK data we are able to exploit differences between companies as they become more 'Americanised' to provide some insight into this question. In the UK there has been a change towards the use of the US terminology CEO and away from the more tradition UK nomenclature of MD. A minority of UK companies retain the terminology MD. Also in some UK companies the top executive is a US citizen. Both these may tell us something about the culture of the company. We test whether tournaments are more likely to be effective if the company calls it top executive CEO and also if there is a US CEO. We find that increasing the dispersion of remuneration is no more effective for companies with CEOs than for MDs. However, we find that the situation is different when we look at companies with US CEOs relative to the rest of the sample. Here we find that increasing the dispersion is associated with better company performance.
\end{abstract}

JEL classification: G35, J33, L29

Key words: Executive compensation, incentive pay, firm performance

\footnotetext{
${ }^{1}$ Tel.: +44 117 9288439; 8 Woodland Road, Bristol, BS8 1TN, UK; E-mail: n.ozkan@bristol.ac.uk.

2 Tel. +44 1603 593415, Norwich, NR4 7TJ, UK; Email: oleksandr.talavera@gmail.com

${ }^{3}$ Corresponding address: School of Management, University of Bath, Bath,BA2 7AY, UK; Tel: +44 0125 384354, Bath, BA2 7AY, UK Email: a.zalewska@bath.ac.uk
} 


\section{Introduction and Brief Literature Review}

Numerous theoretical and empirical studies show that the size and structure of executive compensation packages play an important role in determining incentives of executives and thereby affect shareholders' wealth and resource allocation in the overall economy. Most of the attention is focused on the compensation of CEOs as company leaders, and there is only a handful of papers which addresses the issue of optimal incentive structures from the perspective of a board as a management team responsible for the wellbeing of a company. A fundamental issue when setting incentives for a team is whether teams work more efficiently when tournament incentives are imposed or whether collegial structures create a more efficient working environment.

Tournament theory suggests that large differences in compensation between the CEO and next highest rank executive can provide motivation for the executives occupying that rank by promoting competition among them (Lazear and Rosen, 1981). Thus, large pay differences may result in higher career incentives and motivate executives to perform better to reach the highest rank with the highest reward (compensation). The strength of these incentives could be particularly important in an agency framework when shirking and free riding arise and monitoring individuals can be impractical. However, behaviourists argue that large pay gaps within the executive teams may lead to failures of coordination since these pay gaps create feelings of relative deprivation among team members and establish temptations for executives to sabotage their team members to win promotion. They argue that a compressed compensation distribution among executives is more efficient because it can reduce sabotage and promote cooperation and team spirit (Milgrom and Roberts, 1988, Lazear, 1989).

Voices against large compensation dispersion come also from practitioners. For instant, Jeffrey Immelt, the CEO of GE, told recently the Financial Times that “...to 
motivate staff and avoid excesses, CEOs' pay should remain within a small multiple of the pay of their 25 most senior managers". ${ }^{4}$ He also added, “...the key relationship is the one between the CEO and the top 25 managers in the company because that is the key team. Should the CEO make five times, three times or twice what this group makes? This is debatable, but 20 times is lunacy".

The empirical literature on the effect of dispersion of executive remuneration (i.e., the extent of a tournament structure) on the comparative performance of companies is mixed. Some studies find positive effects whilst others find very little or no effect at all. Interestingly, the existing support for the tournament hypothesis comes from the US studies, while the non-US samples do not seem to support the hypothesis. For instance, Main et al. (1993) in a sample of over 200 U.S. corporations from 1980 to 1984 find that wage-dispersing incentive structures enhance economic performance. They fail to support the hypothesis of superiority of pay equity among the top executives in U.S. corporations. More recently, Lee et al. (2008) examine 1855 US companies over the period 1992 to 2003 and find support for the tournament theory, i.e., they show that firm performance is positively associated with the dispersion of executive compensation. However, Eriksson (1999) reports a weak association between executive pay dispersion and firm performance for a sample of Danish firms from 1992 to 1995. Also Conyon et al. (2001) find that variation in executive pay across different ranks does not have a significant impact on firm performance using data on 100 UK companies in 1998.

This suggests that tournaments are likely to be more effective in some situations than others. In this paper we investigate whether tournament incentives, as measured by the pay dispersion are positively associated with the firm performance as measured by return on assets (ROA), return on equity (ROE), return on capital employed (ROCE), and

\footnotetext{
4 "Immelt wades into debate over pay", November 32006 , Financial Times
} 
profit margin (PM) using a sample of 964 UK firms listed on the London Stock Exchange over the period 2000-2008.

Using the UK sample has several advantages. In particular it gives an opportunity to exploit differences between companies as they become more 'Americanised' to provide some insight into whether tournaments are indeed more likely to be more successful under some circumstances than others. Specifically, in the UK there has been a change over the last 30 years in the terminology of the top executive in a company. The move has been towards the use of the US terminology Chief Executive Officer (CEO) and away from the more tradition UK nomenclature of Managing Director (MD). However, a minority, but still significant, proportion of UK companies retain the terminology MD. The decision not to change the title of the top executive may tell us something about the culture of the company and so we test whether tournaments are more likely to be effective if the company calls it top executive CEO as opposed to MD.

Of course, the shift from MD to CEO is simply a change in name and does not guarantee that there is any difference in culture. However, some UK companies have US nationals sitting on the board, and in some the top executive is a US citizen. Interestingly, these are all CEO's, there are no US MDs in our sample. The choice of a US CEO may also be informative about the culture of a company. So we test whether tournaments are more likely to be effective if (i) the company has American board members, and then (ii) it has chosen a US citizen as the top executive.

The literature on tournaments has typically used the ratio of standard deviation to the mean remuneration of the board as a measure of the extent of a tournament structure in a company. We use this as a measure but a problem with this measure is that there may be board members who may never be competing for the position of MD or CEO. Of course, if we are simply concerned with the effect of the dispersion of board remuneration on performance then this is not an issue. However, to the extent that the 
dispersion of remuneration is used as a measure of the tournament intensity in a remuneration system then this causes a problem. The ideal solution would be to identify the pool of company candidates who are in a position where there is a realistic chance of progressing to $\mathrm{CEO}$ or $\mathrm{MD}$ and to look at the dispersion of remuneration within this group. This information is not available but in the UK a company's finance director (FD) is almost certainly in the pool of potential CEO/MD candidates and so we also look at the ratio of $\mathrm{CEO} / \mathrm{MD}$ 's remuneration to FD's remuneration as an alternative measure of tournament intensity. ${ }^{5}$

For the whole sample we find no evidence that greater dispersion of remuneration is associated with better performance even with a wide array of controls. Indeed, where there is an effect we find if anything that it is associated with lower performance. When we investigate whether tournaments are more effective in companies with CEOs than those with MDs (i.e., we look at the interaction effect) we find that increasing the dispersion of remuneration within the board is no more effective for CEOs than for others and that increasing the relative remuneration of CEOs to FDs is associated with worse performance. Similarly, there is only weak evidence that boards which have American members respond better to tournament incentive structures than boards without Americans, although the inability to find anything but a very weak effect could be due to the dearth of US nationals on UK boards. But the situation is different when we look at companies with US CEOs relative to the rest of the sample. Here we find that, regardless of whether we measure dispersion by the dispersion of board remuneration or the ratio of CEO to FD compensation, increasing the dispersion is associated with better company performance.

\footnotetext{
${ }^{5}$ Indeed, in our sample we identified 296 internal promotions. Out of these 67 , or $22.6 \%$ were from a position of FD, and it was the most numerous group.
} 
The rest of the paper is organized as follows. Section 2 describes data and presents summary statistics. Section 3 reports empirical results, and Section 4 concludes.

\section{Data and Variable Construction}

\subsection{Data Sources}

The data have been collected from four sources: BoardEx, Datastream/Worldscope, Thomson One Banker, and directly from annual company reports. BoardEx provides information on executive compensation and board characteristics. We have used the detailed information it provides on components of executive compensation packages including salaries, bonuses, long-term incentive plans, share awards, stock options, and other pay $^{6}$. We have also collected information about board structures (i.e., names of executive and nonexecutive members), and characteristics of individual members of the board such as nationality, education, tenure in the current firm and in the current position, and age. Annual company reports were consulted whenever more detailed information about board structure was required. This was mostly to clarify position and responsibility of board members when BoardEx data were missing or insufficient (e.g., all board members were called 'executive directors' without any specification who was responsible for finances, operation, etc.)

From Datastream/Worldscope we collected accounting information necessary to calculate performance measures and control for firm characteristics. More precisely we collected the following statistics: net income before tax and dividends, net sales, total debt, total assets, total liabilities liabilities, common shareholder equity.

From Thomson One Banker we have collected information on institutional and insider share ownership.

\footnotetext{
${ }^{6}$ Boardex is a UK-based data base provided by Management Diagnostic Limited.
} 


\subsection{Sample selection}

Using the above sources we aimed to collected data on all publicly traded nonfinancial UK companies over the period 2000-2008. We start the sample in 2000 to give maximum coverage of board characteristics from BoardEx ${ }^{7}$, and finish in 2008 as this is the most recent year for which BordEx data are available at the time of writing the paper.

To make the sample suitable for the analysis we applied the following screening procedure to calculate dispersion measures. First, from each year we excluded those executive board members for which annual compensation components were not available (e.g., the reported salary referred to a few months of employment an executive was in post). Second, we removed all company-year observations for which we had complete information about remuneration for less than three executive board members. Third, we removed all the company-year observations for which there was no information about CEO or MD (e.g., a company was in a process of appointing a CEO or MD). In the majority of companies it is clear who the top executive is, because there is only one person in each year branded as CEO, MD and, occasionally, CEO/MD. In the case of a few companies which reported having both an MD and a CEO, and they were two different executives, we consulted corresponding annual reports to find the relevant job descriptions and decided on an individual bases who the top executive was. In majority of cases it was the CEO who was the top executive, however, in a couple of cases we assigned MD as the top executive.

To be able to lag some of the dependent variables (a crude way of dealing with endogeneity embedded in the data) we excluded all companies for which data for only one year was available. In this way we obtained an unbalanced panel of 4,870 companyyear observations for the 1105 non-financial UK companies listed on the London Stock Exchange in the period 2000-2008.

\footnotetext{
${ }^{7}$ There is some data in Boardex in 1999, but for a relatively small number of companies.
} 
Next we married these observations with the financial data collected from Datastream/Worldscope and Thomson One Banker. We could not find accounting and ownership data for every company with information about boards. Therefore, our sample was reduced to 964 non-financial UK companies. Therefore, in total, the sample that is used as the base for the analysis is an unbalanced panel of 4,120 company-year observations (all together 17,913 data points). The sample includes 1,529 individual top executives (CEOs or MDs), 4,017 executive board members and 3,437 non-executive board members.

In regressions controlling for nationality of executives further reduction in the data occurs due to a lack of information. Because BordEx does not provide nationality for 314 CEOs included in our sample, the panel was further reduced to 3,445 company-year observations.

\subsection{Definition of the variables}

To assess company performance using accounting data available from Datastream we collected four performance measures: return on assets (ROA), return on equity (ROE), return on capital employed (ROCE) and profit margin $(\mathrm{PM}){ }^{8}$ These ratios are commonly used to assess efficiency with which management teams use assets to generate earnings. Interestingly, ROCE is the most common measure used by the UK Competition Commission to assess firms' profitability in abuse monopoly cases. ${ }^{9}$

\footnotetext{
${ }^{8}$ Using these statistics we defined ROCE $=$ net income before extrapfddivs/(total assets - liabilities); Leverage $=$ total debt/total assets; $\mathrm{ROA}=$ net income before extrapfddivs/total assets; Profit Margin $=$ net income before extrapfddivs/net sales; $\mathrm{ROE}=$ net income before extrapfddivs/common shareholders equity

${ }^{9}$ We do not discuss market performance measure such as Tobin's Q and Market-to-book ratio. This is because when a high proportion of remuneration depends on equity (hence on a state of the LSE) changes in stock prices can change dispersion (since there are systematic differences in executives' proportions of equity remuneration), which can create a spurious relationship. Indeed, this is a problem for our sample because it captures two meltdowns of the LSE, one after the burst of the E-commerce bubble at the beginning of the sample, and one at the end of the sample, in the Credit Crunch.
} 
In addition, we collected several firm level statistics to control for board and firm characteristics. These are:

- SALES - controlling for size is important because a top executive may be awarded relatively more than the other board members in big corporations than in small firms. Table 1B shows that the median top executive in a small company earns $49 \%$ more than his FD, whereas this difference is as much as $90 \%$ for the largest companies. This may reflect the fact that CEO/MD's responsibility may be much more complex in big firms than in small firms. In particular, if a big corporation has a big board, individual non-top executives may be responsible for relatively smaller tasks resulting in a higher dispersion of remuneration. In regressions we use natural logarithm of sales, $\ln ($ SALES) to smooth the data.

- LEVERAGE - is defined as the ratio of total debt/total assets; we control for leverage because this is an important measure of a firm's financial health. Recent anecdotal evidence also suggests that during the financial-crisis 2007-2010 temporary increases in stock prices (resulting in high equity linked performance payments) were due to increases in leverage, therefore, we control for the impact of leverage on performance.

- BOARD_SIZE, i.e., the size of the board which is calculated as the total number of executive and non-executive directors sitting on a board;

- BOARD_INDEP, i.e., the ratio of the number of independent directors to the size of the board; Lee et al. (2008) find that there is a stronger positive association between firm performance and pay dispersion in companies with highly independent boards. On the other hand, Franks et al (2001) find that nonexecutive directors do not perform a disciplinary function in UK companies. In 
the light of these findings, we include board independence to control for possible effects on performance and dispersion.

- INSIDER_OWNER, i.e., the fraction of shares held by insiders such as directors, officers, immediate families, any other corporate individuals; Short and Keasey (1999) show that although there are important differences in the UK and the US governance systems, insider ownership remains an important factor determining performance of UK companies.

- INSTIT_OWNER, denotes the fraction of outstanding shares held by financial institutions. We control for institutional ownership because there is some evidence that institutional owners impact on the determination of top executive pay and, in particular, have a positive and significant impact on CEO payperformance sensitivity of option grants (Ozkan, 2009). Also Cornett et al. (2007) find that institutional ownership plays a significant role in determining firm performance. Moreover, during the period of this study, i.e, 2000-2008 institutional investors were quite active in acquiring shares of UK companies. Although, on average, in our sample the percentage of shares owned by institutions remained more-or-less constant at $28 \%$, there are big variations within different group sizes. For instance, in the quartile of smallest companies the average institutional ownership dropped from $16.3 \%$ in 2000 to $14.8 \%$ in 2008 . In contrast, in the top quartile it increased from $31.4 \%$ to $43.9 \%$ over the same period of time.

The descriptive statistics for the above variables are presented in Table 2. For regression purposes to diminish effects of outliers all the financial variables have been winsorized at the top and bottom $1 \%$ level.

In addition, we constructed several variables to control for managerial characteristics: 
- $\mathrm{CEO}$ - is a dummy equal to 1 when a top manager is called a CEO and zero if he/she is called an MD;

- US_CEO - is a dummy equal to one if nationality of a top manger is

American and zero otherwise. In our sample there are no MDs of American nationality;

- OVSEAS - is a dummy equal to one if nationality of a top manager is neither British nor American;

- USBOARD - is a percentage of American nationals sitting on a board in a particular year. This ratio is calculated using both executive and non executive members of the board.

\subsection{Remuneration Dispersion Measures}

We constructed two measures of remuneration dispersion which we use for each of three different measures of remuneration: salary, cash compensation (i.e., salary plus bonus), and total compensation (i.e., cash compensation plus equity linked compensation). This gives six dispersion measures in total. ${ }^{10} \mathrm{We}$ focus on salary, cash compensation and total compensation because we believe that they are good reflections of the different financial advantages of particular positions. It is well documented, and can also be seen in Table 1A, that the top executives are on average better paid than the other executive members of a board. The average total compensation of the top executive is $72 \%$ higher than the average compensation of the other executive board members. This difference in total compensation is more pronounced for large firms, where an average top executive earns $92 \%$ more than the average executive board member (Table 1B).

\footnotetext{
${ }^{10}$ BoardEx computes the value of options granted in a given year by using the closing stock price on the last trading day of the fiscal year rather than the stock price on the grant date. This is because for some companies specific grant date is not available in the company annual reports from where BoardEx collects the compensation data for UK companies. For computing the value of long term incentive plans or stock awards, BoardEx again uses the end-of-fiscal year closing stock price.
} 
Hence, if the size of remuneration is what executives value, then total compensation is the informative variable to use. ${ }^{11}$ The compensation, however, has several components which may make a particular job less or more financially appealing. It can be seen in Table 1A that the equity link part of compensation is higher for top executives than for Finance Directors ((47\% compared to $41 \%$ on average, Table $1 \mathrm{~A}$ Panel B), and more skewed. The salary component is smaller for the top executives (31\%) than for Finance Directors who on average have $39 \%$ of their total compensation in the form of salary. A similar picture emerges when comparing the top executives with other board members (Table 1A Panels C). The differences in the relative sizes of remuneration components between top executives and the other board members is even more pronounced when one separates between small and large firms (Table 1B, Panel C).

This means that top executives receive more equity linked incentives than the non-top executives, hence a greater proportion of top executives total compensation depends on stock market fluctuations. ${ }^{12}$ Therefore, although total compensation is important, we believe that the proportion of the 'secure' part of it may also provide a powerful incentive or disincentive. Therefore, in our analysis we also discuss the salary and cash compensation components. The cash compensation is an interesting element because, although a bonus is not guaranteed, recent events show that in spite of financial difficulties and severe market underperformance, top executives still receive high bonuses, which suggests that bonuses are a rather more certain part of the remuneration package than the name may suggest.

The above discussion clearly suggests that measuring dispersion is not as straightforward as one would wish for. Lee et. al. (2008) discuss the remuneration

\footnotetext{
${ }^{11}$ We do not discuss other benefits of becoming the top executive such as increase in power, influence, etc. as they are not easily measurable and such a consideration goes beyond the scope of this paper.

${ }^{12}$ This is consistent with other studies, e.g., Barron and Waddell (2003), Aggarwal and Samwick (2003), Ang et.al. (2002).
} 
dispersion from the perspective of the group, that is, they look at the standard deviation of remuneration of the board normalised by the mean remuneration. Following their approach we define the dispersion of the board remuneration as:

$$
\text { DispBoard }_{\mathrm{i}, \mathrm{t} \text {, renumeration }}=\frac{(\text { Standard deviation of the remuneration of the board })_{\mathrm{i}, \mathrm{t}}}{(\text { Average remuneration of the board })_{\mathrm{i}, \mathrm{t}}},
$$

where $\mathrm{i}$ is a company specific indicator, $\mathrm{t}$ denotes time, and remuneration is salary, cash compensation or total compensation.

Because the above measure is based on the remuneration of all executive members of the board it is useful when testing the impact of the remuneration dispersion at the team level. It is not, however, informative when one wishes to address the issue of competition between individuals. For instance, if we consider that becoming a top executive is the ultimate goal of one's career, then the remuneration dispersion between the top executive and potential promotion candidates should be examined. This, however, brings the question of who should be compared against the CEO as a potential benchmark of dispersion. It is quite common to compare the top paid executive, with the second best paid executive, with the third best paid executive, etc., (e.g., Ang et. al. (2002)), but in our sample CEOs and MDs are not necessarily the best paid executives making the ranking of the executives by the size of remuneration confusing and incorrect. ${ }^{13}$ Therefore, we also believe it is useful to rank executives by their responsibility and we compare the top executives against the Finance Director (FD) in their firm. We believe that the position of Finance Director provides a valid comparison, as typically the FD is a

\footnotetext{
${ }^{13}$ There are several reasons why CEOs and MDs are not always the best paid executives. One is that a founder of a company may sit on the board and, although he/she is not the CEO of the firm, the money compensation he/she receives is much higher than any other member of the board. Another reason for a $\mathrm{CEO} / \mathrm{MD}$ being paid less is a sudden raise/decline in the value of equity/options that for individual year observations can make other members of the board to be much better paid than the CEO/MD if the $\mathrm{CEO} / \mathrm{MD}$ had a higher proportion of equity linked assets in his/her remuneration portfolio.
} 
powerful executive who oversees financial decisions of a company including such vital decisions as M\&A, projects development, etc. Moreover, in our sample as indicated earlier FDs have the highest promotion rate among board members.

Therefore, the second remuneration dispersion measure employed in the paper is defined as:

$$
\text { DispTop/FD }{ }_{\mathrm{i}, \mathrm{t}, \text { renumeration }}=\frac{(\text { Remuneration of the top executive })_{\mathrm{i}, \mathrm{t}}}{(\text { Remuneration of the Finance Director })_{\mathrm{i}, \mathrm{t}}},
$$

where, as previously, $\mathrm{i}$ is a company specific indicator, $\mathrm{t}$ denotes time, and remuneration is a salary, cash compensation or total compensation. ${ }^{14}$

Before the regression model specifications are discussed, a few words should be devoted to the statistical properties of the dispersion measures. Table 3 shows the summary of the basic statistics of both dispersion measures. In Table 3 Panel A reports results for all firms, while Panels $\mathrm{B}$ and $\mathrm{C}$ describe remuneration dispersions for small and large companies, respectively. An interesting observation comes from the statistics of coefficient of variation, DispBoard. The data reveal that this normalized dispersion measure is higher for large companies compared to their smaller counterparts for all three remuneration types. Furthermore, the coefficient of variation for all three measures of compensation appear to be right skewed. Similarly, the distribution of the dispersion measure based on CEO to FD, i.e., DispTop/FD, is also positively skewed with the median of salary (total compensation) equal to 1.562 (1.596). On average a top executive receives $76 \%(84 \%)$ higher salary (total compensation) than an FD.

\footnotetext{
${ }^{14}$ Kale et al. (2009) define dispersion as $\log$ (total compensation of CEO - median value of the total compensation of all VPs in the firm-year). Following this we defined a dispersion measure as the ratio of the top executive's remuneration to the median of the remuneration of all the other executives sitting on the board. However, this measure was highly correlated with the DispBoard measure so we did not pursue this for our analysis.
} 


\section{Model Specification and Empirical Results}

This section presents the results of the econometric analysis. Section 3.1 discusses results of the basic regression model which assesses the link between the remuneration dispersion and performance. Section 3.2 enriches the basic model by adding dummies and interactive effects to capture the effect of the CEO/MD distinction and Section 3.3 adds dummies and interactive effects to investigate whether the impact of remuneration dispersion on performance differs for companies with American nationals sitting on a board. Section 4 closes with conclusions.

\subsection{Dispersion and Performance}

To investigate whether and how differences in remuneration across the board affect a company's performance we run a series of regressions:

$$
\text { performance }_{\mathrm{c}, \mathrm{t}}=\sum_{k} \delta_{k}(\text { controls })_{c, t-1}+\lambda(\text { DISPERSION })_{\mathrm{c}, \mathrm{t}-1}+\varepsilon_{c, t}
$$

where, the control variables are $\ln (\mathrm{SALES})$, LEVERAGE, BOARD_SIZE, BOARDINDEP, INSIDER_OWNER, INSTIT_OWNER as explained in Section 2.3. In addition we control for industry-specific effects and time effects. DISPERSION is DispTop/FD or DispBoard as defined in Section 2.4. As the performance measures we use ROA, ROE, ROCE and PM. In total, for each of the four performance measures we run six regressions, of which three are for the DispTop/FD (for salary, cash compensation and total compensation), and three for the DispBoard (for salary, cash compensation and total compensation). $\varepsilon_{c t}$ is the error term.

The four performance measures are broadly used in the literature and by practitioners. Each of these measures assesses performance from a slightly different 
angle, so by using all four we should be able to explore in more depth the link between the performance measures and the dispersion ratios of executive remuneration. However, as the definitions of the measures are not distinct, it should not come as a surprise that the measures are correlated with each other. Table 4 shows that, indeed, it is only PM and ROE that are correlated less than 50\%, and ROCE and ROA are correlated at $93 \%$. Obviously, regression specifications that use highly correlated dependent variables can be expected to deliver similar results. As this is a case indeed, to save space we present results for all four performance measure only for the first set of results (Table 5). In the following tables we only resent the results obtained for ROE, ROCE and PM. We drop ROA because of its high correlation with ROCE and PM. ${ }^{15}$

It may also be important to explain a potential drawback of using both the board size and the firm size variables in one regression equation. It is well documented that bigger firms have bigger boards, therefore, using BAORD_SIZE and $\ln ($ SALES) brings a potential problem of multicolinearity. Indeed, in our sample the correlation between BOARD_SIZE and $\ln ($ SALES) is 53\%, which although not low, is still not high enough to provide a clear case for the exclusion of one of the two variables. Indeed, as the regression results show the coefficients estimated for BOARD_SIZE and for $\ln$ (SALES) are often both statistically significant, giving us a good justification for keeping both variables in the equation specification.

Finally, before we discuss the regression results, we should devote a few words to an endogeneity issue. We cannot rule out a possibility that even if remuneration dispersion impacts on firms' performance, the performance itself may result in changes in the award structure. For instance, if a particular executive's efforts have resulted in a superior firm performance, he/she may be awarded extra compensation, which may alter the comparative compensation structure of the board (temporarily or permanently).

\footnotetext{
${ }^{15}$ Although not presented the ROA results can be obtained from the authors on request.
} 
Therefore, the issue of the link between the performance and remuneration dispersion has an embedded endogeneity problem. To deal with this potential obstacle, we lagged the right-hand side variables of specification (3), i.e., we lagged the controls (firm, and board characteristics) as well as the dispersion measures. Although, lagging may not completely solve the endogeneity issue (if present), it should reduce its effect. To check for robustness of our results we also performed a Fixed Effects Two-Stage Least Square (FE2SLS) analysis. The models were estimated using a first difference transformation to remove the individual firm effect. As there is no theoretical model that specifies a choice of instrumental variables, we followed the empirical study by Kale et al. (2009) which faced a similar issue of endogeneity when testing for the impact of tournament payment structures on firm performance. More specifically, we instrument DISPERSION and LEVERAGE variables by median values of DISPERSION, LEVERAGE and TOTAL COMPENSATION of the firms that are in the same industry and belong to the same size quartile. The results obtained using the FE-2SLS specification were consistent with the results obtained for the OLS with the lagged dependent variables as specified by Equation (3) and are presented in Appendix. In the rest of the paper we present results for the OLS regressions only.

Table 5 presents the first set of results. Panels A, B, C and D show results for the ROA, ROE ROCE and PM, respectively. Each panel consists of six columns. The first two show the results for the dispersion of the salary, the middle two columns show the results for the dispersion of cash compensation and the last two for the dispersion of total compensation. Each of these pairs shows results first for DispTop/FD and then for DispBoard.

The coefficients estimated for several control variables are statistically significant. The bigger the company is, the better performance (the positive coefficient for the $\ln ($ SALES)). In all regressions LEVERAGE has a negative impact on the performance 
measures, but the estimated coefficients are not statistically significant safe for two (at the $10 \%$ level). BOARD_SIZE is negatively associated with all the performance measures, all the coefficients are statistically significant. The proportion of the independent directors sitting on a board (BOARD_INDEP) shows the strongest statistical associations for ROCE, and no statistical significance or ROE. Insider ownership (INSIDER_OWNER) matters only in the ROA regressions and institutional ownership (INSTIT_OWNER) comes mildly significant (10\%) in the ROCE regressions.

The coefficients estimated for the dispersion measures do not provide evidence in support of the claim that greater dispersion of remuneration is associated with the better firm performance. All the statistically significant coefficients estimated for the four performance measures are negative. Dispersion seems to have the weakest impact on PM,

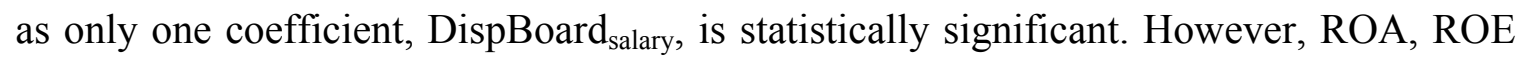
and ROCE show several DISPERSION coefficients significant at 1\% and 5\% levels.

The results show that dispersion appears to have a negative impact on performance, which contradicts the tournament hypothesis. Interestingly, the DispBoard's coefficients are bigger in absolute terms for all performance specifications, and more statistically significant with an exception of these estimated for ROE as the dependent variable. Furthermore, the impact of dispersion is material. For example, the average dispersion of the salaries of board members is 0.347 . So, moving from a situation of zero dispersion (all board members are paid the same) to the average dispersion results in $0.112 \times 0.347=3.8 \%$ fall in ROA.

In the light of the above discussion we conclude that Table 5 does not provide support for the tournament hypothesis for UK companies, which is consistent with previous non-American studies. 


\subsection{Are CEOs different from MDs?}

As discussed in the Introduction and Section 2.1, top UK executives are historically known as MDs. In the last few decades, however, there has been an observed departure away from calling the top executive MDs in favour of the American terminology of CEO. Indeed, in our sample only 129 companies were run by MDs. Therefore, it is interesting to test whether this 'Americanisation' is reflected in the change of the name only, or whether the change is more fundamental and having a CEO as opposed to MD means that the higher remuneration dispersion benefits companies.

To address this issue we modify Equation (3). We add a CEO dummy which is equal to 1 when the top executive is called a CEO and zero when he/she is called an MD. ${ }^{16}$ To test whether the effectiveness of CEOs increases with the size of dispersions we also include an interactive term, CEO times the corresponding dispersion measure. Thus, Equation (3) becomes:

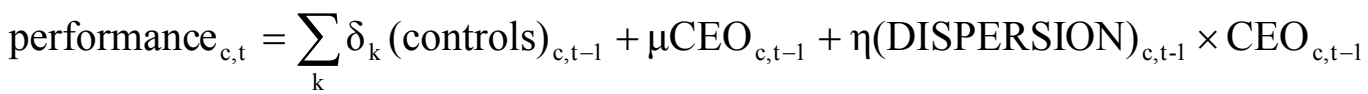

$$
\begin{aligned}
& +\lambda(\text { DISPERSION })_{\mathrm{c}, \mathrm{t}-1}+\varepsilon_{\mathrm{c}, \mathrm{t}}
\end{aligned}
$$

If the move away from MD to CEO is purely 'terminological', then it should not matter whether a company is run by a CEO or an MD. In other words, the CEO dummy and the interactive term should be insignificant. Table 6 shows the results. As explained in Section 3.1 to save space we show results for ROE, ROCE and PM only. The coefficients for the control variables are very similar, in magnitude and statistical significance, to those presented in Table 5. The coefficients estimated for the CEO

\footnotetext{
${ }^{16}$ There is a handful of cases that an executive is branded as CEO/MD in the Boardex database. In such cases we consulted an annual report. If the executive signs a report as CEO he/she has CEO dummy equal to 1 , if, however, he/she signs as an MD, his/her value of the CEO dummy is zero.
} 
dummies are insignificant with an exception of the one estimated for DispBoard salary $_{\text {in }}$ the regression using PM as the dependent variable. Only two of the coefficients estimated for DispTop/FD and DispBoard are statistically significant, of which one coefficient is negative and one is positive. This seems to dilute the picture of the negative association of the dispersion measures with the performance measures, but still it is impossible to conclude that there is any support for the tournament hypothesis.

Contrary to the literature, it is CEO-run companies who, if anything, underperform when the remuneration dispersion increases. All statistically significant coefficients, but one, of the interactive terms are negative, and the only positive one is statistically significant at the $10 \%$ level. It should be noted that increasing the difference between the CEO and FD seems more damaging to the firm than a high dispersion within the board. It shows that companies with CEOs do not differ that much from companies with MDs, but if they do they do for worse.

\subsection{Does having Americans on a board make a difference?}

We have just concluded that tournaments do not appear to be effective in the British context, i.e., if anything, a high dispersion of financial compensation between a CEO and close team mates, and in particular, with FDs, has a negative impact on the various performance measures. However, not all companies are the same. One can imagine that people respond better to structures and incentives they are familiar with. Newman and Nollen (1996) conclude that “...financial performance is higher when management practices in the work unit are congruent with national culture". This means that 'foreign' structures may not adapt well to 'local' culture, but this however, can also suggest that if foreigners work abroad, they may respond better to what is their 'local' culture even if this is foreign in the country they work. In the light of this argument controlling for 'foreignness' may be important and informative. Because previous studies 
suggest that remuneration tournament structures provide positive incentives in the USA we test whether having Americans on a board makes ta difference.

Companies that have American nationality board members may have a different culture than other UK companies and certainly hiring an American CEO is a clear statement of culture than simply changing the title from MD to CEO.

BoardEx does not provide nationality data for all the board members, therefore we remove from the sample all these observations for which the nationality is not known. This reduces our sample to 724 companies. In this sample 45 CEOs are recorded to have the American nationality.

\section{American non-CEO board members and tournament compensation structures}

As indicated, since the tournament remuneration structures seem to work well at the US (see, e.g., Main et al. (1993) and Lee et al. (2008)), we ask whether boards with higher proportion of American members respond better to tournament compensation structures. The distribution of the proportion of Americans sitting on boards of UK companies is very bimodal. More than half of the companies in our sample do not have American board members, and on average there are only $0.3 \%$ of Americans sitting on boards. However, the top $10 \%$ of companies have on average over a third of their board members (36\%) of American nationality.

To test whether boards with more Americans respond positively to tournament structures we add to Equation (3) one more control variable, USBOARD, that as described in Section 2.3 measures the proportion of American board members to all board members after an exclusion of CEO/MD. Therefore, the new model specification is: 


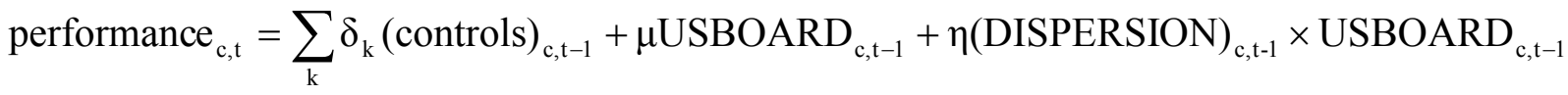

$$
\begin{aligned}
& +\lambda(\text { DISPERSION })_{\mathrm{c}, \mathrm{t}-1}+\varepsilon_{\mathrm{c}, \mathrm{t}}
\end{aligned}
$$

Table 7 shows the results and confirms our earlier findings that the dispersion has a negative impact on performance. Including Americans as 'ordinary' board members does not seem to improve performance either (none of the coefficients estimated for the USBOARD is significant), although one of the coefficients estimated for the interactive term (USBOARD x DISPERSION) is statistically significantly different from zero (at the $10 \%$ level) and positive. Furthermore, the majority of the insignificant ones are positive.

In the light of this, we clearly cannot conclude that admitting a few Americans to a board makes an entire board respond better to tournament compensation structures, than if only non-Americans were on a board. In one sense, this is not surprising. Given that Americans are on average less than a half of one percent of board members and almost no boards get even close to majority, then it is very hard for them to change the culture of the entire board. This is supported by the data which suggests some very weak evidence that boards with American board members may respond differently to tournament incentives. This suggests if we are to find an effect we should turn our attention to the most influential board member, a CEO/MD.

\section{American CEOs and tournament compensation structures}

To test whether having an American CEO matters we introduce a dummy, US_CEO (equal to one if the nationality of the CEO is American and zero otherwise) to Equation (3). That is, our new model specification becomes: 


$$
\begin{aligned}
\text { performance }_{\mathrm{c}, \mathrm{t}}= & \sum_{\mathrm{k}} \delta_{\mathrm{k}}(\text { controls })_{\mathrm{c}, \mathrm{t}-1}+\mu \mathrm{US}_{-} \mathrm{CEO}_{\mathrm{c}, \mathrm{t}-1}+ \\
& +\eta(\text { DISPERSION })_{\mathrm{c}, \mathrm{t}-1} \times \mathrm{US}_{-} \mathrm{CEO}_{\mathrm{c}, \mathrm{t}-1}+\lambda(\text { DISPERSION })_{\mathrm{c}, \mathrm{t}-1}+\varepsilon_{\mathrm{c}, \mathrm{t}}
\end{aligned}
$$

Table 8 present the results. The US_CEO dummy is statistically significant in several regressions and when significant it has a negative impact on the firm performance. However, the interactive term captures whether companies that have US_CEOs respond differently to tournaments than other UK companies. We find that in all the regressions in which the US_CEO dummy is significant the interactive term of having an American CEO and high dispersion of remuneration has a positive and statistically significant coefficient. ${ }^{17}$ This can be interpreted as suggesting that companies that hire American nationality CEOs and perhaps these CEOs themselves respond well to tournament incentives.

To check for robustness of these findings we run one more set of regressions. This time we control for top managers having the American nationality (via the US_CEO dummy, as previously), and for top managers having a non-British and non-American nationality (the OVSEAS dummy). Therefore, Equation (4) becomes now

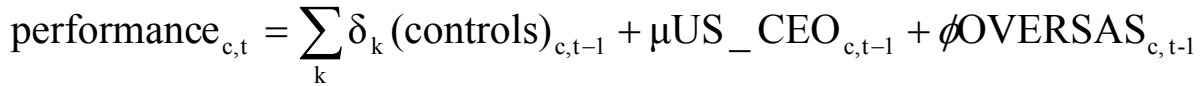

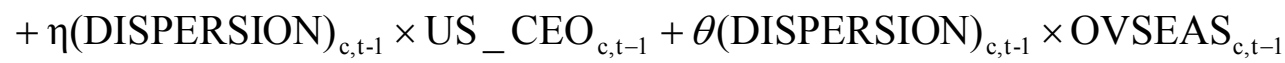

$$
\begin{aligned}
& +\lambda(\text { DISPERSION })_{\mathrm{c}, \mathrm{t}-1}+\varepsilon_{\mathrm{c}, \mathrm{t}}
\end{aligned}
$$

Table 9 proves that indeed being an American top manager (CEO in our sample) makes the difference. None of the coefficients of the OVSEAS dummy or the interaction terms

\footnotetext{
${ }^{17}$ This also is the case of the regressions for ROA which are not presented. The two statistically significant coefficients of the interactive term were obtained for DispBoard calculated for salary, and DispTop/FD calculated for cash compensation.
} 
containing the dummy is statistically significant. At the same time all the results presented in Table 8 are preserved.

It is interesting that none of the coefficients estimated for the total DispTop/FD total

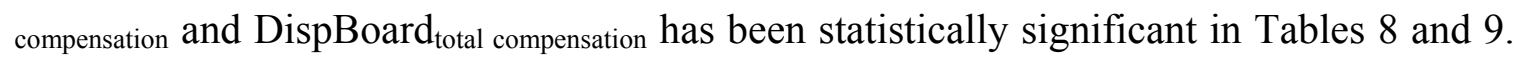
It suggests that it is the 'guaranteed' parts of the compensation (i.e., salary and bonus) that have the strongest impact on how executives feel and what motivates them to work hard when differences in remuneration are in place.

\section{Conclusion}

Imposing the right incentive on managers is one of the fundamental issues of the corporate governance literature. The optimal incentive structures are typically discussed from the perspective of CEOs as the leaders of the management team and there are only a handful of papers that look at the remuneration structures of the management team. These papers consider the effect of dispersion of executive remuneration (i.e., the extent of a tournament structure) on the comparative performance of companies and find mixed results. In particular, studies on US data tend to find strong effects, i.e., higher dispersion is associated with better performance, but non-US studies tend to fail to find an effect. This paper contributes to this growing strand of the literature, by discussing whether high dispersion between the top manager and his/her board colleagues is associated with better performance for UK companies and whether there is a difference in the relationship between companies that have CEOs compared to those that have MDs and between UK companies with US board members and other UK companies. We analyse these effects using a sample of 964 companies listed on the London Stock Exchange in the period 2000-2008.

The advantage of using UK data is that we are able to exploit differences between companies as they become more 'Americanised'. We use the CEO/MD distinction and 
the presence of US board members (and CEOs) to capture differences in corporate culture and attitudes. This research shows that the UK executive boards do not find the 'winner takes it all' incentive structure appealing. This is the case even if they have chosen to use to the terminology CEO (the American name) as opposed to MD (the British name). However, our findings show that the tournament structures of compensation work well for companies that have a US CEO. This helps explain the differences in the findings of existing research and emphasises the extent that corporate culture may be important in determining whether tournaments are helpful in improving company performance. 


\section{References}

Aggarwal, R., and A. Samwick, 2003. Performance incentives within firms: the effect of managerial responsibility, Journal of Finance 58, 1613-1650.

Ang, J., Lauterbach, B., and B.Z. Schreiber, 2002. Pay at the executive suit: How do US banks compensate their top management teams?, Journal of Banking and Finance 26, 1143-1163.

Barron, J.M., and G.R.Waddell, 2003. Executive rank, pay, and project selection, Journal of Financial Economics 67, 305-349.

Conyon, M.J., Peck, S.I., and G.V. Sadler, , 2001. Corporate tournaments and executive compensation: Evidence from the UK, Strategic Management Journal 22, 805-815.

Core, J., W. R. Guay, and D. F. Larcker. 2003. Executive Equity Compensation and Incentives:A Survey. Economic Policy Review 9, 27-50.

Cornett, M.M., A.J. Marcus, S. Saunders and H. Tehranian, 2007, The impact of institutional ownership on corporate operating performance, Journal of Banking and Finance, 31, 1771-1794.

Eriksson, T., 1999, Executive compensation and tournaments theory: Empirical tests on Danish data, Journal of Labour Economics 17, 262-280.

Franks, J., C. Mayer and L. Renneboog, 2001, Who disciplines management in poorly performing companies?, Journal of Financial Intermediation 10, 209-48.

Kale, J., Reis, E., and A.Venkateswaran, 2009. Rank order tournament and incentive alignment: The effect on firm performance, Journal of Finance 64, 1479-1512.

Lazear, E.P., 1989, Pay equality and industrial politics, Journal of Political Economy 97, 561-580.

Lazear, E.P., and S. Rosen, 1981, Rank-order tournaments as optimum labour contracts. Journal of Political Economy 89, 841-864.

Lee, K.W., Lev, B., and G.H.H. Yeo, 2008, Executive pay dispersion, corporate governance, and firm performance, Review of Quantitative Finance and Accounting 30, 315-338.

Main, B.G.M, O’Reilly, and C.A., Wade, J., 1993, Top executive pay: Tournament or teamwork?, Journal of Labour Economics 11(4), 606-628.

Milgrom, P., and J. Roberts, 1988, An economic approach to influence activities in organizations, American Journal of Sociology 94, 154-159.

Newmann, K.L., and S.D. Nollen, 1996, Culture and congruence: The fit between management practices and national culture, Journal of International Business Studies, 753-779 
Ozkan, N., 2009, CEO compensation and firm performance: An empirical investigation of UK panel data, European Financial Management, (forthcoming)

Short, H. and K. Keasy, 1999, Managerial ownership and the performance of firms:

Evidence from the UK, Journal of Corporate Finance 5, 79-101. 


\section{Appendix}

\section{Fixed Effect Two-Stage Least Square robustness check.}

To check the robustness of our results we estimate the Equation (3) specification without lagging the independent variables, i.e.,

$$
\text { performance }_{\mathrm{c}, \mathrm{t}}=\sum_{k} \delta_{k}(\text { controls })_{c, t}+\lambda(\text { DISPERSION })_{\mathrm{c}, \mathrm{t}}+\varepsilon_{c, t}
$$

with the Fixed Effects Two-Stage Least Square (FE-2SLS) estimator. The specifications of the model (i.e., the combinations of four performance measures with the three dispersion specifications for DisBoard and the three specifications for the DisTop/FD, all together 24 specifications) are estimated using a first difference transformation to remove the individual firm effect. In the spirit of Kale et al. (2009) we instrumented DISPERSION and LEVERAGE variables by median values of DISPERSION, LEVERAGE and TOTAL COMPENSATION of the firms that are in the same industry and belong to the same size quartile. ${ }^{18}$

The reliability of our econometric methodology depends crucially on the validity of instruments, which can be evaluated with Sargan's test for overidentifying restrictions, and LM test for underidentification. As Table A1 shows the instruments pass both tests for all 24 specifications. To save space $\ln ($ SALES), LEVERAGE, BOARD_SIZE, BOARD_INDEP, INSIDER_OWNER, INSTIT_OWNER, constant, industry and year dummy variables are not reported.

\footnotetext{
${ }^{18}$ We have experimented with treating all firm-specific variables as endogenous as well as with treating ownership variables as endogenous. The results were similar to reported in Table A1.
} 
Table A1. FE-2SLS regression results. Asymptotic cluster-robust standard errors are reported in parentheses. LM is the p-value of the LM underidentification test. $\mathrm{J}$ is the p-value of Sargen's J test of overidentifying restrictions. $* * *$ - significant at $1 \%$ level, $* *$ - significant at $5 \%$ level and * - significant at $10 \%$ level.

\begin{tabular}{|c|c|c|c|c|c|c|}
\hline \multirow[b]{2}{*}{ Panel A: ROA } & \multicolumn{2}{|c|}{ Salary } & \multicolumn{2}{|c|}{ Cash Compensation } & \multicolumn{2}{|c|}{ Total Compensation } \\
\hline & DispTOP/FD & DispBoard & DispTOP/FD & DispBoard & DispTOP/FD & DispBoard \\
\hline DISPERSION & $\begin{array}{c}-0.015^{*} \\
(0.009)\end{array}$ & $\begin{array}{l}-0.071 \\
(0.066)\end{array}$ & $\begin{array}{l}-0.014^{*} \\
(0.009)\end{array}$ & $\begin{array}{l}-0.039 \\
(0.065)\end{array}$ & $\begin{array}{c}-0.018 * * \\
(0.008)\end{array}$ & $\begin{array}{l}-0.012 \\
(0.044)\end{array}$ \\
\hline LM & 0.00 & 0.00 & 0.00 & 0.00 & 0.00 & 0.00 \\
\hline $\mathrm{J}$ & 0.33 & 0.27 & 0.33 & 0.28 & 0.37 & 0.25 \\
\hline
\end{tabular}

Salary

Cash Compensation

Total Compensation

\begin{tabular}{|c|c|c|c|c|c|c|}
\hline Panel B: ROE & DispTOP/FD & DispBoard & DispTOP/FD & DispBoard & DispTOP/FD & DispBoard \\
\hline \multirow[t]{2}{*}{ DISPERSION } & -0.060 & -0.424 & $-0.063^{*}$ & $-0.496^{*}$ & $-0.071 * *$ & -0.024 \\
\hline & $(0.037)$ & $(0.293)$ & $(0.036)$ & $(0.287)$ & $(0.033)$ & $(0.191)$ \\
\hline LM & 0.00 & 0.00 & 0.00 & 0.00 & 0.00 & 0.00 \\
\hline \multirow[t]{2}{*}{$\mathrm{J}$} & 0.70 & 1.00 & 0.70 & 0.94 & 0.81 & 0.98 \\
\hline & \multicolumn{2}{|c|}{ Salary } & \multicolumn{2}{|c|}{ Cash Compensation } & \multicolumn{2}{|c|}{ Total Compensation } \\
\hline Panel C: ROCE & DispTOP/FD & DispBoard & DispTOP/FD & DispBoard & DispTOP/FD & DispBoard \\
\hline \multirow[t]{2}{*}{ DISPERSION } & 0.007 & $-0.101 * *$ & 0.005 & -0.026 & -0.005 & $-0.054^{*}$ \\
\hline & $(0.007)$ & $(0.047)$ & $(0.007)$ & $(0.046)$ & $(0.006)$ & $(0.031)$ \\
\hline LM & 0.00 & 0.00 & 0.00 & 0.00 & 0.00 & 0.00 \\
\hline \multirow[t]{2}{*}{$\mathrm{J}$} & 0.29 & 0.35 & 0.29 & 0.36 & 0.35 & 0.52 \\
\hline & \multicolumn{2}{|c|}{ Salary } & \multicolumn{2}{|c|}{ Cash Compensation } & \multicolumn{2}{|c|}{ Total Compensation } \\
\hline Panel D: PM & DispTOP/FD & DispBoard & DispTOP/FD & DispBoard & DispTOP/FD & DispBoard \\
\hline \multirow[t]{2}{*}{ DISPERSION } & 0.005 & $-0.088^{* *}$ & 0.004 & -0.055 & -0.002 & -0.023 \\
\hline & $(0.005)$ & $(0.040)$ & $(0.005)$ & $(0.039)$ & $(0.005)$ & $(0.026)$ \\
\hline LM & 0.00 & 0.00 & 0.00 & 0.00 & 0.00 & 0.00 \\
\hline $\mathrm{J}$ & 0.83 & 0.46 & 0.83 & 0.52 & 0.87 & 0.56 \\
\hline
\end{tabular}


Table 1(A). The structure of executive compensation in UK listed companies, 2000-2008

\begin{tabular}{|c|c|c|c|c|}
\hline \multicolumn{5}{|c|}{ Panel A: CEO/MD } \\
\hline & \multicolumn{4}{|c|}{ Compensation } \\
\hline Variable & Mean value & Mean value, $\%$ & Median value & S.D. \\
\hline Base salary & 281.19 & 31 & 223.42 & 204.38 \\
\hline Bonus & 136.91 & 15 & 44.97 & 271.79 \\
\hline Other & 63.36 & 7 & 26.85 & 190.63 \\
\hline Equity & 426.83 & 47 & 68.12 & $1,347.50$ \\
\hline Total Comp & 908.28 & 100 & 441.73 & $1,631.91$ \\
\hline \multicolumn{5}{|c|}{ Panel B: Finance Director } \\
\hline & \multicolumn{4}{|c|}{ Compensation } \\
\hline Variable & Mean value & Mean value, $\%$ & Median value & S.D. \\
\hline Base salary & 149.19 & 39 & 125.79 & 98.75 \\
\hline Bonus & 50.08 & 13 & 16.59 & 87.06 \\
\hline Other & 27.41 & 7 & 16.77 & 44.08 \\
\hline Equity & 159.46 & 41 & 29.15 & 588.51 \\
\hline Total Comp & 386.14 & 100 & 215.85 & 679.36 \\
\hline \multicolumn{5}{|c|}{ Panel C: Executive board members with CEO/MD excluded } \\
\hline Variable & Mean value & Mean value, $\%$ & Median value & S.D. \\
\hline Base salary & 178.39 & 34 & 147.56 & 125.29 \\
\hline Bonus & 77.41 & 14 & 26.74 & 160.96 \\
\hline Other & 35.47 & 7 & 18.87 & 74.29 \\
\hline Equity & 236.58 & 45 & 41.62 & $1,126.12$ \\
\hline Total Comp & 527.84 & 100 & 278.49 & $1,215.76$ \\
\hline \multicolumn{5}{|c|}{ Panel D: All Board } \\
\hline Variable & Mean value & Mean value, $\%$ & Median value & S.D. \\
\hline Base salary & 204.46 & 33 & 161.29 & 155.92 \\
\hline Bonus & 92.50 & 15 & 30.08 & 196.82 \\
\hline Other & 42.54 & 7 & 20.41 & 116.11 \\
\hline Equity & 284.83 & 45 & 45.61 & $1,189.03$ \\
\hline Total Comp & 624.33 & 100 & 311.93 & $1,343.83$ \\
\hline
\end{tabular}


Table 1(B). The structure of executive compensation in smallest and largest UK listed companies, 20002008.

\begin{tabular}{|c|c|c|c|c|c|c|}
\hline \multicolumn{7}{|c|}{ Panel A: CEO/MD } \\
\hline & \multicolumn{3}{|c|}{ Smallest firms } & \multicolumn{3}{|c|}{ Largest firms } \\
\hline Variable & Mean value & Median value & S.D. & Mean value & Median value & S.D. \\
\hline Base salary & 133.05 & 116.16 & 68.81 & 449.35 & 400.39 & 215.26 \\
\hline Bonus & 21.01 & 0.00 & 46.35 & 267.71 & 172.22 & 360.01 \\
\hline Other & 17.31 & 13.89 & 18.85 & 105.00 & 51.44 & 163.78 \\
\hline Equity & 61.85 & 0.00 & 158.22 & 765.65 & 307.82 & $1,680.68$ \\
\hline Total Comp & 233.22 & 165.25 & 204.69 & $1,587.71$ & $1,013.82$ & $2,044.22$ \\
\hline \multicolumn{7}{|c|}{ Panel B: Finance Director } \\
\hline & \multicolumn{3}{|c|}{ Smallest firms } & \multicolumn{3}{|c|}{ Largest firms } \\
\hline Variable & Mean value & Median value & S.D. & Mean value & Median value & S.D. \\
\hline Base salary & 85.90 & 83.86 & 49.98 & 249.60 & 227.76 & 105.38 \\
\hline Bonus & 11.71 & 0.00 & 32.49 & 115.15 & 85.95 & 129.75 \\
\hline Other & 11.21 & 6.00 & 14.80 & 48.82 & 28.00 & 64.35 \\
\hline Equity & 39.82 & 0.00 & 109.70 & 295.85 & 160.53 & 422.24 \\
\hline Total Comp & 148.63 & 111.10 & 145.29 & 709.42 & 533.28 & 597.12 \\
\hline \multicolumn{7}{|c|}{ Panel C: Executive board members with CEO/MD excluded } \\
\hline & \multicolumn{3}{|c|}{ Smallest firms } & \multicolumn{3}{|c|}{ Largest firms } \\
\hline Variable & Mean value & Median value & S.D. & Mean value & Median value & S.D. \\
\hline Base salary & 94.22 & 87.00 & 53.89 & 262.55 & 236.56 & 137.54 \\
\hline Bonus & 16.17 & 0.00 & 125.54 & 143.16 & 93.00 & 208.27 \\
\hline Other & 12.23 & 7.00 & 19.42 & 54.34 & 28.34 & 101.66 \\
\hline Equity & 39.63 & 0.00 & 111.59 & 365.45 & 164.69 & 676.69 \\
\hline Total Comp & 162.24 & 120.52 & 193.43 & 825.50 & 560.01 & 877.68 \\
\hline \multicolumn{7}{|c|}{ Panel D: All Board } \\
\hline & \multicolumn{3}{|c|}{ Smallest firms } & \multicolumn{3}{|c|}{ Largest firms } \\
\hline Variable & Mean value & Median value & S.D. & Mean value & Median value & S.D. \\
\hline Base salary & 104.73 & 93.07 & 60.77 & 306.61 & 265.39 & 177.95 \\
\hline Bonus & 17.48 & 0.00 & 109.87 & 172.54 & 104.08 & 257.87 \\
\hline Other & 13.60 & 8.58 & 19.39 & 66.29 & 31.34 & 121.17 \\
\hline Equity & 45.65 & 0.00 & 126.23 & 459.85 & 190.15 & $1,022.08$ \\
\hline Total Comp & 181.46 & 131.01 & 198.95 & $1,005.29$ & 642.35 & $1,295.54$ \\
\hline
\end{tabular}


Table 2. Descriptive statistics of the independent variables; Q1, Q2 and Q3 denote the $25^{\text {th }}, 50^{\text {th }}$ and $75^{\text {th }}$ percentiles of distribution, respectively. $\mathrm{N}$ is the number of observations.

\begin{tabular}{lcccccc}
\hline & $\underline{\text { Mean }}$ & $\underline{\mathrm{StDev}}$ & $\underline{\mathrm{Q} 1}$ & $\underline{\mathrm{Q} 2}$ & $\underline{\mathrm{Q} 3}$ & $\underline{\mathrm{N}}$ \\
$\ln ($ Sales $)$ & 12.039 & 2.313 & 10.584 & 12.071 & 13.726 & 11,604 \\
LEVERAGE & 0.193 & 0.179 & 0.038 & 0.170 & 0.292 & 11,636 \\
BOARD_SIZE & 9.346 & 2.969 & 7.000 & 9.000 & 11.000 & 11,630 \\
BOARD_INDEP & 0.467 & 0.126 & 0.375 & 0.500 & 0.556 & 11,630 \\
INSIDER_OWNER & 0.271 & 0.219 & 0.092 & 0.238 & 0.422 & 11,601 \\
INSTIT_OWNER & 0.318 & 0.192 & 0.168 & 0.311 & 0.454 & 11,636 \\
\hline
\end{tabular}


Table 3. Basic statistics of the dispersion measures

Panel A: All Firms

\begin{tabular}{lcccccc}
\hline & Mean & StDev & Q1 & Q2 & Q3 & N \\
\hline Salary: DispTop/FD & 1.763 & 1.197 & 1.333 & 1.562 & 1.824 & 9,670 \\
\hline Salary: DipsBoard & 0.347 & 0.172 & 0.234 & 0.320 & 0.426 & 11,596 \\
\hline Cash Comp: DispTop/FD & 1.842 & 1.324 & 1.335 & 1.586 & 1.912 & 9,670 \\
\hline Cash Comp: DipsBoard & 0.372 & 0.197 & 0.245 & 0.341 & 0.458 & 11,596 \\
\hline Total Comp: DispTop/FD & 1.843 & 1.344 & 1.325 & 1.596 & 1.950 & 9,701 \\
\hline Total Comp: DipsBoard & 0.395 & 0.217 & 0.253 & 0.357 & 0.488 & 11,636 \\
\hline
\end{tabular}

Panel B: Small Firms

\begin{tabular}{lcccccc}
\hline & Mean & StDev & Q1 & Q2 & Q3 & N \\
\hline Salary: DispTop/FD & 1.937 & 1.945 & 1.118 & 1.481 & 1.938 & 636 \\
\hline Salary: DipsBoard & 0.338 & 0.234 & 0.171 & 0.295 & 0.426 & 924 \\
\hline Cash Comp: DispTop/FD & 1.965 & 1.973 & 1.144 & 1.520 & 2.107 & 636 \\
\hline Cash Comp: DipsBoard & 0.357 & 0.248 & 0.178 & 0.319 & 0.461 & 924 \\
\hline Total Comp: DispTop/FD & 1.883 & 1.721 & 1.143 & 1.490 & 2.192 & 644 \\
\hline Total Comp: DipsBoard & 0.356 & 0.241 & 0.176 & 0.332 & 0.463 & 938 \\
\hline
\end{tabular}

Panel C: Large Firms

\begin{tabular}{lcccccc}
\hline & Mean & StDev & Q1 & Q2 & Q3 & N \\
\hline Salary: DispTop/FD & 1.805 & 1.050 & 1.458 & 1.622 & 1.843 & 4,610 \\
\hline Salary: DipsBoard & 0.371 & 0.154 & 0.273 & 0.337 & 0.451 & 5,401 \\
\hline Cash Comp: DispTop/FD & 1.895 & 1.185 & 1.468 & 1.651 & 1.936 & 4,610 \\
\hline Cash Comp: DipsBoard & 0.398 & 0.180 & 0.286 & 0.366 & 0.473 & 5,401 \\
\hline Total Comp: DispTop/FD & 1.914 & 1.237 & 1.462 & 1.681 & 1.980 & 4,610 \\
\hline Total Comp: DipsBoard & 0.421 & 0.198 & 0.294 & 0.382 & 0.509 & 5,401 \\
\hline
\end{tabular}

Q1, Q2 and Q3 denote the $25^{\text {th }}, 50^{\text {th }}$ and $75^{\text {th }}$ percentiles of distribution, respectively. $\mathrm{N}$ is the number of observations. 
Table 4. Correlation coefficients of the performance measures. All the off-diagonal correlations are significant at the $1 \%$ level.

\begin{tabular}{|c|c|c|c|c|}
\hline & ROA & ROE & ROCE & PM \\
\hline ROA & 1 & & & \\
\hline ROE & 0.93 & 1 & & \\
\hline ROCE & 0.58 & 0.56 & 1 & \\
\hline PM & 0.66 & 0.77 & 0.37 & 1 \\
\hline
\end{tabular}


Table 5. Regression results of the equation specification

performanc $_{\mathrm{c}, \mathrm{t}}=\sum_{\mathrm{k}} \delta_{\mathrm{k}}\left(\right.$ controls $_{\mathrm{c}, \mathrm{t}-1}+\lambda(\text { DISPERSION })_{\mathrm{c}, \mathrm{t}-1}+\varepsilon_{\mathrm{c}, \mathrm{t}}$

where performance is measured by the return on assets (ROA, Panel A) or return on equity (ROE, Panel B), and return on capital employed (ROCE, Panel C), and profit margin (PM). DISPERSION is either the ratio of the top executive's remuneration to the FD's remuneration (DispTop/FD) or the standard deviation of the remuneration of board executive members to the mean remuneration of the board (DispBoard) each of which is calculated for salary, cash compensation and total compensation. BOARD SIZE is the size of the board which is calculated as the total umber of executive and non-executive directors sitting on a board, BOARD_INDEP, is a ratio of the number of independent directors to the size of the board, INSIDEROWNER is a fraction of shares held by insiders, INSTIT_OWNER is a fraction of outstanding shares held by financial institutions. Constant, industry and year dummy variables are included as controls but not reported. Firm-clustered standard errors are in parentheses. *** - significant at the $1 \%$ level, ** significant at the $5 \%$ level and $*$-significant at the $10 \%$ level.

\begin{tabular}{|c|c|c|c|c|c|c|}
\hline \multirow[b]{2}{*}{ Panel A:ROA } & \multicolumn{2}{|c|}{ Salary } & \multicolumn{2}{|c|}{ Cash Compensation } & \multicolumn{2}{|c|}{ Total Compensation } \\
\hline & DispTop/FD & DipsBoard & DispTop/FD & DipsBoard & DispTop/FD & DipsBoard \\
\hline \multirow[t]{2}{*}{$\ln ($ SALES $)$} & $0.047 * * *$ & $0.050 * * *$ & $0.047^{* * *}$ & $0.050 * * *$ & $0.047 * * *$ & $0.050 * * *$ \\
\hline & $(0.007)$ & $(0.006)$ & $(0.007)$ & $(0.006)$ & $(0.007)$ & $(0.006)$ \\
\hline \multirow[t]{2}{*}{ LEVERAGE } & -0.133 & -0.125 & -0.129 & -0.126 & -0.122 & -0.122 \\
\hline & $(0.102)$ & $(0.083)$ & $(0.103)$ & $(0.083)$ & $(0.101)$ & $(0.082)$ \\
\hline \multirow[t]{2}{*}{ BOARD_SIZE } & $-0.011 * * *$ & $-0.011 * * *$ & $-0.011 * * *$ & $-0.011 * * *$ & $-0.011 * * *$ & $-0.011 * * *$ \\
\hline & $(0.003)$ & $(0.003)$ & $(0.003)$ & $(0.003)$ & $(0.003)$ & $(0.003)$ \\
\hline \multirow[t]{2}{*}{ BOARD_INDEP } & -0.078 & $-0.096^{*}$ & -0.085 & $-0.101^{*}$ & -0.082 & $-0.100^{*}$ \\
\hline & $(0.054)$ & $(0.054)$ & $(0.055)$ & $(0.055)$ & $(0.055)$ & $(0.054)$ \\
\hline \multirow[t]{2}{*}{ INSIDER_OWNER } & $0.067 * *$ & $0.073 * *$ & $0.072 * *$ & $0.074 * *$ & $0.072 * *$ & $0.074 * *$ \\
\hline & $(0.030)$ & $(0.031)$ & $(0.031)$ & $(0.031)$ & $(0.031)$ & $(0.032)$ \\
\hline \multirow[t]{2}{*}{ INSTIT_OWNER } & 0.004 & 0.017 & 0.006 & 0.018 & 0.004 & 0.018 \\
\hline & $(0.033)$ & $(0.032)$ & $(0.034)$ & $(0.033)$ & $(0.034)$ & $(0.033)$ \\
\hline \multirow[t]{2}{*}{ DISPERSION } & $-0.025 * *$ & $-0.112 * * *$ & -0.018 & $-0.080 * *$ & -0.018 & $-0.052 *$ \\
\hline & $(0.013)$ & $(0.038)$ & $(0.012)$ & $(0.035)$ & $(0.012)$ & $(0.028)$ \\
\hline Observations & 2,377 & 2,891 & 2,377 & 2,891 & 2,386 & 2,903 \\
\hline Adjusted R2 & 0.21 & 0.21 & 0.20 & 0.21 & 0.20 & 0.20 \\
\hline \multicolumn{7}{|l|}{ Panel B: ROE } \\
\hline \multirow[t]{2}{*}{$\ln ($ SALES $)$} & $0.064 * * *$ & $0.078 * * *$ & $0.064 * * *$ & $0.077 * * *$ & $0.065 * * *$ & $0.076 * * *$ \\
\hline & $(0.013)$ & $(0.012)$ & $(0.013)$ & $(0.012)$ & $(0.013)$ & $(0.012)$ \\
\hline \multirow[t]{2}{*}{ LEVERAGE } & -0.073 & -0.035 & -0.060 & -0.034 & -0.051 & -0.031 \\
\hline & $(0.173)$ & $(0.148)$ & $(0.174)$ & $(0.148)$ & $(0.172)$ & $(0.146)$ \\
\hline \multirow[t]{2}{*}{ BOARD_SIZE } & $-0.014 * *$ & $-0.013 * *$ & $-0.013^{*}$ & $-0.012 * *$ & $-0.012 *$ & $-0.012 * *$ \\
\hline & $(0.007)$ & $(0.006)$ & $(0.007)$ & $(0.006)$ & $(0.007)$ & $(0.006)$ \\
\hline \multirow[t]{2}{*}{ BOARD_INDEP } & -0.093 & -0.106 & -0.111 & -0.115 & -0.115 & -0.118 \\
\hline & $(0.243)$ & $(0.212)$ & $(0.242)$ & $(0.210)$ & $(0.242)$ & $(0.210)$ \\
\hline \multirow[t]{2}{*}{ INSIDER_OWNER } & 0.084 & 0.137 & 0.097 & 0.138 & 0.098 & 0.138 \\
\hline & $(0.105)$ & $(0.100)$ & $(0.105)$ & $(0.100)$ & $(0.104)$ & $(0.100)$ \\
\hline \multirow[t]{2}{*}{ INSTIT_OWNER } & 0.058 & 0.062 & 0.065 & 0.066 & 0.058 & 0.065 \\
\hline & $(0.126)$ & $(0.112)$ & $(0.124)$ & $(0.112)$ & $(0.124)$ & $(0.112)$ \\
\hline \multirow[t]{2}{*}{ DISPERSION } & $-0.070 * * *$ & $-0.215^{*}$ & $-0.062 * * *$ & $-0.196^{*}$ & $-0.054 * *$ & -0.120 \\
\hline & $(0.026)$ & $(0.116)$ & $(0.024)$ & $(0.106)$ & $(0.025)$ & $(0.077)$ \\
\hline Observations & 2,362 & 2,872 & 2,362 & 2,872 & 2,371 & 2,884 \\
\hline Adjusted R2 & 0.06 & 0.07 & 0.06 & 0.07 & 0.06 & 0.07 \\
\hline
\end{tabular}


Panel C: ROCE

\begin{tabular}{|c|c|c|c|c|c|c|}
\hline $\ln ($ SALES) & $\begin{array}{c}0.035^{* * *} \\
(0.005)\end{array}$ & $\begin{array}{c}0.038^{* * *} \\
(0.004)\end{array}$ & $\begin{array}{c}0.035^{* * *} * \\
(0.005)\end{array}$ & $\begin{array}{c}0.038 * * * \\
(0.004)\end{array}$ & $\begin{array}{c}0.035 * * * \\
(0.005)\end{array}$ & $\begin{array}{c}0.038^{* * * *} \\
(0.004)\end{array}$ \\
\hline LEVERAGE & -0.071 & $-0.067^{*}$ & -0.071 & $-0.068^{*}$ & -0.071 & $-0.069^{*}$ \\
\hline & $(0.045)$ & $(0.039)$ & $(0.046)$ & $(0.039)$ & $(0.045)$ & $(0.039)$ \\
\hline BOARD_SIZE & $\begin{array}{c}-0.009^{* * *} \\
(0.003)\end{array}$ & $\begin{array}{c}-0.010^{* * *} \\
(0.003)\end{array}$ & $\begin{array}{c}-0.009^{* * *} \\
(0.003)\end{array}$ & $\begin{array}{c}-0.010 * * * \\
(0.003)\end{array}$ & $\begin{array}{c}-0.009^{* * *} \\
(0.003)\end{array}$ & $\begin{array}{c}-0.009 * * * \\
(0.003)\end{array}$ \\
\hline BOARD_INDEP & $\begin{array}{c}-0.136^{* * *} \\
(0.046)\end{array}$ & $\begin{array}{c}-0.132 * * * \\
(0.044)\end{array}$ & $\begin{array}{c}-0.141 * * * \\
(0.047)\end{array}$ & $\begin{array}{c}-0.135^{* * *} \\
(0.044)\end{array}$ & $\begin{array}{c}-0.142 * * * \\
(0.047)\end{array}$ & $\begin{array}{c}-0.137 * * * \\
(0.044)\end{array}$ \\
\hline INSIDER_OWNER & $\begin{array}{c}0.042 \\
(0.033)\end{array}$ & $\begin{array}{c}0.044 \\
(0.031)\end{array}$ & $\begin{array}{c}0.044 \\
(0.034)\end{array}$ & $\begin{array}{c}0.044 \\
(0.031)\end{array}$ & $\begin{array}{c}0.045 \\
(0.034)\end{array}$ & $\begin{array}{c}0.046 \\
(0.031)\end{array}$ \\
\hline INSTIT_OWNER & $\begin{array}{l}0.066^{*} \\
(0.038)\end{array}$ & $\begin{array}{c}0.050 \\
(0.035)\end{array}$ & $\begin{array}{l}0.066^{*} \\
(0.038)\end{array}$ & $\begin{array}{c}0.051 \\
(0.035)\end{array}$ & $\begin{array}{l}0.066^{*} \\
(0.038)\end{array}$ & $\begin{array}{c}0.051 \\
(0.036)\end{array}$ \\
\hline DISPERSION & $\begin{array}{c}-0.013^{*} \\
(0.006)\end{array}$ & $\begin{array}{c}-0.061 * * \\
(0.030)\end{array}$ & $\begin{array}{l}-0.005 \\
(0.005)\end{array}$ & $\begin{array}{l}-0.031 \\
(0.029)\end{array}$ & $\begin{array}{c}-0.008^{*} \\
(0.005)\end{array}$ & $\begin{array}{l}-0.037 \\
(0.023)\end{array}$ \\
\hline Observations & 2,293 & 2,779 & 2,293 & 2,779 & 2,302 & 2,791 \\
\hline Adjusted R2 & 0.19 & 0.22 & 0.19 & 0.22 & 0.19 & 0.22 \\
\hline Panel D: PM & & & & & & \\
\hline $\ln ($ SALES $)$ & $\begin{array}{c}0.014 * * * \\
(0.005)\end{array}$ & $\begin{array}{c}0.017 * * * \\
(0.005)\end{array}$ & $\begin{array}{c}0.014 * * * \\
(0.005)\end{array}$ & $\begin{array}{c}0.016 * * * \\
(0.005)\end{array}$ & $\begin{array}{c}0.014 * * * \\
(0.005)\end{array}$ & $\begin{array}{c}0.016 * * * \\
(0.005)\end{array}$ \\
\hline LEVERAGE & $\begin{array}{c}-0.003 \\
(0.026)\end{array}$ & $\begin{array}{c}0.003 \\
(0.025)\end{array}$ & $\begin{array}{c}-0.003 \\
(0.026)\end{array}$ & $\begin{array}{c}0.003 \\
(0.026)\end{array}$ & $\begin{array}{c}-0.001 \\
(0.026)\end{array}$ & $\begin{array}{c}0.003 \\
(0.025)\end{array}$ \\
\hline BOARD_SIZE & $\begin{array}{c}-0.004^{*} \\
(0.002)\end{array}$ & $\begin{array}{c}-0.005 * * \\
(0.002)\end{array}$ & $\begin{array}{c}-0.004 * * \\
(0.002)\end{array}$ & $\begin{array}{c}-0.005^{* *} \\
(0.002)\end{array}$ & $\begin{array}{c}-0.004 * * \\
(0.002)\end{array}$ & $\begin{array}{c}-0.005 * * \\
(0.002)\end{array}$ \\
\hline BOARD_INDEP & $\begin{array}{c}-0.074^{*} \\
(0.038)\end{array}$ & $\begin{array}{l}-0.044 \\
(0.037)\end{array}$ & $\begin{array}{c}-0.076^{*} \\
(0.039)\end{array}$ & $\begin{array}{l}-0.048 \\
(0.037)\end{array}$ & $\begin{array}{c}-0.073^{*} \\
(0.038)\end{array}$ & $\begin{array}{l}-0.048 \\
(0.037)\end{array}$ \\
\hline INSIDER_OWNER & $\begin{array}{c}-0.031 \\
(0.025)\end{array}$ & $\begin{array}{l}-0.020 \\
(0.024)\end{array}$ & $\begin{array}{l}-0.030 \\
(0.025)\end{array}$ & $\begin{array}{l}-0.020 \\
(0.024)\end{array}$ & $\begin{array}{l}-0.031 \\
(0.025)\end{array}$ & $\begin{array}{l}-0.021 \\
(0.024)\end{array}$ \\
\hline INSTIT_OWNER & $\begin{array}{c}0.019 \\
(0.022)\end{array}$ & $\begin{array}{c}0.019 \\
(0.024)\end{array}$ & $\begin{array}{c}0.018 \\
(0.022)\end{array}$ & $\begin{array}{c}0.019 \\
(0.024)\end{array}$ & $\begin{array}{c}0.019 \\
(0.022)\end{array}$ & $\begin{array}{c}0.021 \\
(0.024)\end{array}$ \\
\hline DISPERSION & $\begin{array}{l}-0.004 \\
(0.004)\end{array}$ & $\begin{array}{c}-0.057 * * \\
(0.024)\end{array}$ & $\begin{array}{c}0.001 \\
(0.003)\end{array}$ & $\begin{array}{l}-0.031 \\
(0.023)\end{array}$ & $\begin{array}{c}0.000 \\
(0.003)\end{array}$ & $\begin{array}{l}-0.026 \\
(0.018)\end{array}$ \\
\hline Observations & 2,286 & 2,734 & 2,286 & 2,734 & 2,295 & 2,745 \\
\hline Adjusted R2 & 0.13 & 0.14 & 0.13 & 0.13 & 0.13 & 0.13 \\
\hline
\end{tabular}


Table 6. Regression results of the equation specification

performance $_{\mathrm{c}, \mathrm{t}}=\sum_{\mathrm{k}} \delta_{\mathrm{k}}(\text { controls })_{\mathrm{c}, \mathrm{t}-1}+\mu \mathrm{CEO}_{\mathrm{c}, \mathrm{t}-1}+\eta(\text { DISPERSION })_{\mathrm{c}, \mathrm{t}-1} \times \mathrm{CEO}_{\mathrm{c}, \mathrm{t}-1}+\lambda(\text { DISPERSION })_{\mathrm{c}, \mathrm{t}-1}+\varepsilon_{\mathrm{c}, \mathrm{t}}$

where performance is measured by the return on equity (ROE, Panel A) and return on capital employed (ROCE, Panel B), and profit margin (PM, Panel C). DISPERSION is either the ratio of the top executive's remuneration to the FD's remuneration (DispTop/FD) or the standard deviation of the remuneration of board executive members to the mean remuneration of the board (DispBoard), each of which is calculated for salary, cash compensation and total compensation. CEO is a dummy equal to one if a company is headed by CEO and zero if it is headed by MD. BOARD_SIZE is the size of the board which is calculated as the total umber of executive and non-executive directors sitting on a board, BOARD_INDEP, is a ratio of the number of independent directors to the size of the board, INSIDER-OWNER is a fraction of shares held by insiders, INSTIT_OWNER is a fraction of outstanding shares held by financial institutions. Constant, industry and year dummy variables are included as controls but not reported. Firm-clustered standard errors are in parentheses.

$* * *$ - significant at the $1 \%$ level, $* *$ - significant at the $5 \%$ level and *-significant at the $10 \%$ level.

\begin{tabular}{|c|c|c|c|c|c|c|}
\hline \multirow[b]{2}{*}{ Panel A:ROE } & \multicolumn{2}{|c|}{ Salary } & \multicolumn{2}{|c|}{ Cash Compensation } & \multicolumn{2}{|c|}{ Total Compensation } \\
\hline & DispTop/F & DipsBoard & DispTop/FD & DipsBoard & DispTop/FD & DipsBoard \\
\hline \multirow[t]{2}{*}{$\ln ($ SALES $)$} & $0.064 * * *$ & $0.078 * * *$ & $0.065^{* * *}$ & $0.078 * * *$ & $0.065 * * *$ & $0.076^{* * *}$ \\
\hline & $(0.013)$ & $(0.012)$ & $(0.013)$ & $(0.012)$ & $(0.013)$ & $(0.012)$ \\
\hline \multirow[t]{2}{*}{ LEVERAGE } & -0.066 & -0.035 & -0.071 & -0.036 & -0.053 & -0.029 \\
\hline & $(0.173)$ & $(0.148)$ & $(0.175)$ & $(0.149)$ & $(0.174)$ & $(0.146)$ \\
\hline \multirow[t]{2}{*}{ BOARD_SIZE } & $-0.013^{* *}$ & $-0.012 * *$ & $-0.014 * *$ & $-0.012 *$ & $-0.012^{*}$ & $-0.011^{*}$ \\
\hline & $(0.007)$ & $(0.006)$ & $(0.007)$ & $(0.006)$ & $(0.007)$ & $(0.006)$ \\
\hline \multirow[t]{2}{*}{ BOARD_INDEP } & -0.072 & -0.076 & -0.070 & -0.081 & -0.083 & -0.087 \\
\hline & $(0.251)$ & $(0.218)$ & $(0.251)$ & $(0.218)$ & $(0.252)$ & $(0.217)$ \\
\hline \multirow[t]{2}{*}{ INSIDER_OWNER } & 0.087 & 0.131 & 0.082 & 0.130 & 0.088 & 0.131 \\
\hline & $(0.105)$ & $(0.100)$ & $(0.105)$ & $(0.100)$ & $(0.104)$ & $(0.099)$ \\
\hline \multirow[t]{2}{*}{ INSTIT_OWNER } & 0.072 & 0.068 & 0.060 & 0.070 & 0.059 & 0.072 \\
\hline & $(0.126)$ & $(0.113)$ & $(0.127)$ & $(0.113)$ & $(0.126)$ & $(0.113)$ \\
\hline \multirow[t]{2}{*}{ CEO } & 0.122 & -0.036 & 0.051 & -0.059 & -0.049 & -0.095 \\
\hline & $(0.091)$ & $(0.075)$ & $(0.094)$ & $(0.071)$ & $(0.103)$ & $(0.066)$ \\
\hline \multirow[t]{2}{*}{ CEO x DISPERSION } & $-0.125 * * *$ & -0.128 & $-0.077^{*}$ & -0.060 & -0.015 & 0.044 \\
\hline & $(0.043)$ & $(0.195)$ & $(0.045)$ & $(0.161)$ & $(0.055)$ & $(0.138)$ \\
\hline \multirow[t]{2}{*}{ DISPERSION } & 0.049 & -0.089 & 0.011 & -0.140 & -0.039 & -0.157 \\
\hline & $(0.033)$ & $(0.173)$ & $(0.038)$ & $(0.134)$ & $(0.050)$ & $(0.122)$ \\
\hline Observations & 2,362 & 2,872 & 2,362 & 2,872 & 2,371 & 2,884 \\
\hline AdjustedR2 & 0.07 & 0.07 & 0.06 & 0.07 & 0.06 & 0.07 \\
\hline \multicolumn{7}{|l|}{ Panel B: ROCE } \\
\hline \multirow[t]{2}{*}{$\ln ($ SALES $)$} & $0.035 * * *$ & $0.038 * * *$ & $0.036 * * *$ & $0.038 * * *$ & $0.036 * * *$ & $0.038 * * *$ \\
\hline & $(0.005)$ & $(0.004)$ & $(0.004)$ & $(0.004)$ & $(0.004)$ & $(0.004)$ \\
\hline \multirow[t]{2}{*}{ LEVERAGE } & -0.071 & $-0.068^{*}$ & $-0.079 *$ & $-0.072 *$ & $-0.082 *$ & $-0.073 *$ \\
\hline & $(0.045)$ & $(0.039)$ & $(0.043)$ & $(0.038)$ & $(0.043)$ & $(0.037)$ \\
\hline \multirow[t]{2}{*}{ BOARD_SIZE } & $-0.009 * * *$ & $-0.009 * * *$ & $-0.010 * * *$ & $-0.010^{* * *}$ & $-0.010 * * *$ & $-0.010^{* * *}$ \\
\hline & $(0.003)$ & $(0.003)$ & $(0.003)$ & $(0.002)$ & $(0.003)$ & $(0.002)$ \\
\hline \multirow[t]{2}{*}{ BOARD_INDEP } & $-0.128 * * *$ & $-0.121 * * *$ & $-0.124 * * *$ & $-0.120 * * *$ & $-0.123 * * *$ & $-0.122 * * *$ \\
\hline & $(0.045)$ & $(0.043)$ & $(0.044)$ & $(0.042)$ & $(0.043)$ & $(0.041)$ \\
\hline \multirow[t]{2}{*}{ INSIDER_OWNER } & 0.041 & 0.042 & 0.038 & 0.040 & 0.038 & 0.042 \\
\hline & $(0.033)$ & $(0.031)$ & $(0.032)$ & $(0.030)$ & $(0.031)$ & $(0.030)$ \\
\hline \multirow[t]{2}{*}{ INSTIT_OWNER } & $0.069^{*}$ & 0.052 & $0.062^{*}$ & 0.050 & $0.061 *$ & 0.051 \\
\hline & $(0.037)$ & $(0.035)$ & $(0.036)$ & $(0.034)$ & $(0.036)$ & $(0.034)$ \\
\hline \multirow[t]{2}{*}{ CEO } & 0.012 & -0.019 & 0.067 & 0.021 & 0.067 & 0.018 \\
\hline & $(0.045)$ & $(0.030)$ & $(0.045)$ & $(0.034)$ & $(0.053)$ & $(0.030)$ \\
\hline \multirow[t]{2}{*}{ CEO $\times$ DISPERSION } & -0.023 & -0.021 & $-0.056^{* *}$ & -0.144 & $-0.056^{*}$ & -0.125 \\
\hline & $(0.020)$ & $(0.075)$ & $(0.024)$ & $(0.096)$ & $(0.032)$ & $(0.086)$ \\
\hline \multirow[t]{2}{*}{ DISPERSION } & 0.010 & -0.039 & $0.047 * *$ & 0.096 & 0.046 & 0.074 \\
\hline & $(0.019)$ & $(0.070)$ & $(0.023)$ & $(0.092)$ & $(0.032)$ & $(0.083)$ \\
\hline Observations & 2,293 & 2,779 & 2,293 & 2,779 & 2,302 & 2,791 \\
\hline AdjustedR2 & 0.19 & 0.22 & 0.19 & 0.22 & 0.19 & 0.22 \\
\hline
\end{tabular}


Continuation of Table 6

\begin{tabular}{lcccccc} 
Panel C: PM & & & & & \\
\cline { 1 - 4 } $\ln ($ SALES) & $0.014^{* * *}$ & $0.017^{* * *}$ & $0.014^{* * *}$ & $0.017^{* * *}$ & $0.014^{* * *}$ & $0.016^{* * *}$ \\
& $(0.005)$ & $(0.005)$ & $(0.005)$ & $(0.005)$ & $(0.005)$ & $(0.005)$ \\
LEVERAGE & -0.003 & 0.003 & -0.006 & 0.003 & -0.005 & 0.002 \\
& $(0.026)$ & $(0.025)$ & $(0.026)$ & $(0.025)$ & $(0.026)$ & $(0.025)$ \\
BOARD_SIZE & $-0.004^{*}$ & $-0.005^{* *}$ & $-0.005^{* *}$ & $-0.005^{* *}$ & $-0.005^{* *}$ & $-0.005^{* *}$ \\
& $(0.002)$ & $(0.002)$ & $(0.002)$ & $(0.002)$ & $(0.002)$ & $(0.002)$ \\
BOARD_INDEPEND & -0.060 & -0.033 & -0.059 & -0.036 & -0.055 & -0.035 \\
& $(0.038)$ & $(0.037)$ & $(0.038)$ & $(0.037)$ & $(0.038)$ & $(0.036)$ \\
INSIDER_OWNER & -0.035 & -0.024 & -0.036 & -0.023 & -0.036 & -0.024 \\
& $(0.025)$ & $(0.023)$ & $(0.025)$ & $(0.023)$ & $(0.024)$ & $(0.023)$ \\
INSTIT_OWNER & 0.020 & 0.021 & 0.018 & 0.022 & 0.018 & 0.022 \\
& $(0.022)$ & $(0.024)$ & $(0.022)$ & $(0.024)$ & $(0.022)$ & $(0.024)$ \\
CEO & -0.033 & $-0.060^{* *}$ & -0.013 & -0.036 & -0.008 & -0.028 \\
& $(0.027)$ & $(0.024)$ & $(0.028)$ & $(0.025)$ & $(0.030)$ & $(0.023)$ \\
CEO x DISPERSION & -0.003 & $0.100^{*}$ & -0.015 & 0.013 & -0.018 & -0.008 \\
& $(0.012)$ & $(0.059)$ & $(0.012)$ & $(0.065)$ & $(0.014)$ & $(0.053)$ \\
DISPERSION & -0.001 & $-0.145^{* * *}$ & 0.015 & -0.041 & 0.017 & -0.018 \\
& $(0.011)$ & $(0.055)$ & $(0.012)$ & $(0.060)$ & $(0.014)$ & $(0.049)$ \\
Observations & 2,286 & 2,734 & 2,286 & 2,734 & 2,295 & 2,745 \\
AdjustedR2 & 0.14 & 0.14 & 0.14 & 0.14 & 0.14 & 0.13 \\
\hline
\end{tabular}


Table 7. Regression results of the equation specification

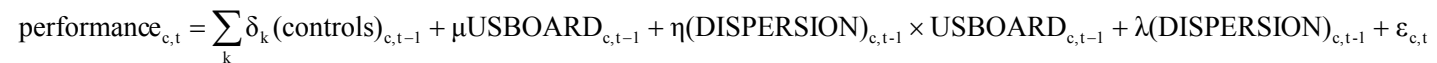

where performance is measured by the return on equity (ROE, Panel A) and return on capital employed (ROCE, Panel B), and profit margin (PM, Panel C). DISPERSION is either the ratio of the top executive's remuneration to the FD's remuneration (DispTop/FD) or the standard deviation of the remuneration of board executive members to the mean remuneration of the board (DispBoard), each of which is calculated for salary, cash compensation and total compensation. USBOARD is a proportion of American board members.

BOARD_SIZE is the size of the board which is calculated as the total umber of executive and non-executive directors sitting on a board, BOARD_INDEP, is a ratio of the number of independent directors to the size of the board, INSIDER-OWNER is a fraction of shares held by insiders, INSTIT_OWNER is a fraction of outstanding shares held by financial institutions. Constant, industry and year dummy variables are included as controls but not reported. Firm-clustered standard errors are in parentheses. *** - significant at the $1 \%$ level, $* *$ - significant at the $5 \%$ level and *-significant at the $10 \%$ level.

\begin{tabular}{|c|c|c|c|c|c|c|}
\hline \multirow[b]{2}{*}{ Panel A:ROE } & \multicolumn{2}{|c|}{ Salary } & \multicolumn{2}{|c|}{ Cash Compensation } & \multicolumn{2}{|c|}{ Total Compensation } \\
\hline & DispTop/FD & DipsBoard & DispTop/FD & DipsBoard & DispTop/FD & DipsBoard \\
\hline \multirow[t]{2}{*}{$\ln ($ SALES $)$} & $0.065 * * *$ & $0.079 * * *$ & $0.066 * * *$ & $0.078 * * *$ & $0.066 * * *$ & $0.077 * * *$ \\
\hline & $(0.013)$ & $(0.012)$ & $(0.013)$ & $(0.012)$ & $(0.013)$ & $(0.012)$ \\
\hline \multirow[t]{2}{*}{ LEVERAGE } & -0.068 & -0.034 & -0.064 & -0.036 & -0.053 & -0.032 \\
\hline & $(0.173)$ & $(0.148)$ & $(0.174)$ & $(0.149)$ & $(0.172)$ & $(0.147)$ \\
\hline \multirow[t]{2}{*}{ BOARD_SIZE } & $-0.013 *$ & $-0.012 *$ & $-0.013 *$ & $-0.011 *$ & $-0.012 *$ & $-0.011 *$ \\
\hline & $(0.007)$ & $(0.006)$ & $(0.007)$ & $(0.006)$ & $(0.007)$ & $(0.006)$ \\
\hline \multirow[t]{2}{*}{ BOARD_INDEP } & -0.139 & -0.132 & -0.149 & -0.137 & -0.153 & -0.141 \\
\hline & $(0.238)$ & $(0.208)$ & $(0.236)$ & $(0.207)$ & $(0.236)$ & $(0.207)$ \\
\hline \multirow[t]{2}{*}{ INSIDER_OWNER } & 0.085 & 0.138 & 0.090 & 0.136 & 0.097 & 0.136 \\
\hline & $(0.106)$ & $(0.101)$ & $(0.106)$ & $(0.100)$ & $(0.104)$ & $(0.100)$ \\
\hline \multirow[t]{2}{*}{ INSTIT_OWNER } & 0.065 & 0.066 & 0.065 & 0.066 & 0.066 & 0.066 \\
\hline & $(0.124)$ & $(0.112)$ & $(0.126)$ & $(0.112)$ & $(0.124)$ & $(0.112)$ \\
\hline \multirow[t]{2}{*}{ USBOARD } & -0.422 & -0.314 & -0.635 & -0.238 & -0.440 & -0.152 \\
\hline & $(0.569)$ & $(0.376)$ & $(0.500)$ & $(0.403)$ & $(0.332)$ & $(0.362)$ \\
\hline USBOARD $\mathrm{x}$ & 0.166 & 0.643 & 0.275 & 0.431 & $0.165^{*}$ & 0.209 \\
\hline DISPERSION & $(0.324)$ & $(0.862)$ & $(0.224)$ & $(0.784)$ & $(0.095)$ & $(0.594)$ \\
\hline \multirow[t]{2}{*}{ DISPERSION } & $-0.074 * * *$ & $-0.234 *$ & $-0.068 * * *$ & $-0.213^{*}$ & $-0.060 * *$ & -0.128 \\
\hline & $(0.029)$ & $(0.127)$ & $(0.026)$ & $(0.117)$ & $(0.027)$ & $(0.083)$ \\
\hline Observations & 2,360 & 2,870 & 2,360 & 2,870 & 2,369 & 2,882 \\
\hline AdjustedR2 & 0.06 & 0.07 & 0.06 & 0.07 & 0.06 & 0.07 \\
\hline \multicolumn{7}{|l|}{ Panel B: ROCE } \\
\hline \multirow[t]{2}{*}{$\ln ($ SALES) } & $0.035 * * *$ & $0.037 * * *$ & $0.035 * * *$ & $0.037 * * *$ & $0.035 * * *$ & $0.038 * * *$ \\
\hline & $(0.005)$ & $(0.004)$ & $(0.005)$ & $(0.004)$ & $(0.005)$ & $(0.004)$ \\
\hline \multirow[t]{2}{*}{ LEVERAGE } & $-0.077 *$ & $-0.068 *$ & -0.073 & $-0.070 *$ & -0.072 & $-0.072 *$ \\
\hline & $(0.044)$ & $(0.039)$ & $(0.044)$ & $(0.038)$ & $(0.045)$ & $(0.038)$ \\
\hline \multirow[t]{2}{*}{ BOARD_SIZE } & $-0.010 * * *$ & $-0.010 * * *$ & $-0.010 * * *$ & $-0.010 * * *$ & $-0.009 * * *$ & $-0.010 * * *$ \\
\hline & $(0.003)$ & $(0.003)$ & $(0.003)$ & $(0.002)$ & $(0.003)$ & $(0.002)$ \\
\hline \multirow[t]{2}{*}{ BOARD_INDEP } & $-0.128 * * *$ & $-0.130 * * *$ & $-0.138 * * *$ & $-0.131 * * *$ & $-0.140 * * *$ & $-0.133 * * *$ \\
\hline & $(0.045)$ & $(0.044)$ & $(0.047)$ & $(0.044)$ & $(0.048)$ & $(0.044)$ \\
\hline \multirow[t]{2}{*}{ INSIDER_OWNER } & 0.040 & 0.044 & 0.042 & 0.044 & 0.045 & 0.046 \\
\hline & $(0.033)$ & $(0.031)$ & $(0.033)$ & $(0.031)$ & $(0.033)$ & $(0.030)$ \\
\hline \multirow[t]{2}{*}{ INSTIT_OWNER } & $0.062 *$ & 0.050 & $0.066^{*}$ & 0.051 & $0.068 *$ & 0.052 \\
\hline & $(0.037)$ & $(0.035)$ & $(0.037)$ & $(0.035)$ & $(0.038)$ & $(0.035)$ \\
\hline \multirow[t]{2}{*}{ USBOARD } & 0.305 & 0.044 & -0.221 & -0.131 & -0.056 & -0.097 \\
\hline & $(0.285)$ & $(0.155)$ & $(0.191)$ & $(0.159)$ & $(0.109)$ & $(0.133)$ \\
\hline USBOARD $\mathrm{x}$ & -0.156 & -0.012 & 0.133 & 0.415 & 0.045 & 0.307 \\
\hline DISPERSION & $(0.154)$ & $(0.337)$ & $(0.091)$ & $(0.343)$ & $(0.036)$ & $(0.252)$ \\
\hline \multirow[t]{2}{*}{ DISPERSION } & -0.008 & $-0.060 *$ & -0.009 & $-0.049 *$ & $-0.011 * *$ & $-0.052 * *$ \\
\hline & $(0.007)$ & $(0.031)$ & $(0.006)$ & $(0.029)$ & $(0.005)$ & $(0.023)$ \\
\hline Observations & 2,291 & 2,777 & 2,291 & 2,777 & 2,300 & 2,789 \\
\hline AdjustedR2 & 0.19 & 0.22 & 0.19 & 0.22 & 0.19 & 0.22 \\
\hline
\end{tabular}


Continuation of Table 7

\begin{tabular}{lllllll} 
Panel C: PM & & & & & \\
In(SALES) & $0.014^{* * *}$ & $0.016^{* * *}$ & $0.014^{* * *}$ & $0.016^{* * *}$ & $0.013^{* *}$ & $0.016^{* * *}$ \\
& $(0.005)$ & $(0.005)$ & $(0.005)$ & $(0.005)$ & $(0.005)$ & $(0.005)$ \\
LEVERAGE & -0.007 & 0.003 & -0.004 & 0.003 & -0.002 & 0.002 \\
& $(0.026)$ & $(0.025)$ & $(0.026)$ & $(0.025)$ & $(0.026)$ & $(0.025)$ \\
BOARD_SIZE & $-0.005^{* *}$ & $-0.005^{* *}$ & $-0.005^{* *}$ & $-0.005^{* *}$ & $-0.005^{* *}$ & $-0.005^{* *}$ \\
& $(0.002)$ & $(0.002)$ & $(0.002)$ & $(0.002)$ & $(0.002)$ & $(0.002)$ \\
BOARD_INDEPENDEN & $-0.073^{*}$ & -0.046 & $-0.081^{* *}$ & -0.049 & $-0.078^{* *}$ & -0.049 \\
& $(0.038)$ & $(0.037)$ & $(0.038)$ & $(0.038)$ & $(0.038)$ & $(0.037)$ \\
INSIDER_OWNER & -0.034 & -0.022 & -0.031 & -0.021 & -0.032 & -0.021 \\
& $(0.025)$ & $(0.024)$ & $(0.025)$ & $(0.024)$ & $(0.025)$ & $(0.023)$ \\
INSTIT_OWNER & 0.015 & 0.018 & 0.018 & 0.020 & 0.020 & 0.021 \\
& $(0.022)$ & $(0.024)$ & $(0.022)$ & $(0.024)$ & $(0.022)$ & $(0.024)$ \\
USBOARD & 0.289 & 0.077 & -0.012 & 0.011 & 0.040 & 0.003 \\
& $(0.198)$ & $(0.122)$ & $(0.131)$ & $(0.113)$ & $(0.079)$ & $(0.101)$ \\
USBOARD x & -0.140 & -0.134 & 0.031 & 0.047 & 0.005 & 0.063 \\
DISPERSION & $(0.112)$ & $(0.283)$ & $(0.058)$ & $(0.228)$ & $(0.019)$ & $(0.167)$ \\
DISPERSION & -0.001 & $-0.052^{* *}$ & -0.000 & -0.033 & -0.000 & -0.030 \\
& $(0.004)$ & $(0.025)$ & $(0.003)$ & $(0.024)$ & $(0.003)$ & $(0.019)$ \\
Observations & 2,285 & 2,733 & 2,285 & 2,733 & 2,294 & 2,744 \\
AdjustedR2 & 0.14 & 0.14 & 0.13 & 0.13 & 0.13 & 0.13 \\
\hline
\end{tabular}


Table 8. Regression results of the equation specification

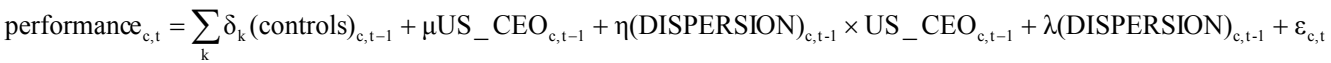

where performance is measured by the return on equity (ROE, Panel A), return on capital employed (ROCE, Panel B), and profit margin (PM, Panel C). For DISPERSION is either the ratio of the top executive's remuneration to the FD's remuneration (DispTop/FD) or the standard deviation of the remuneration of board executive members to the mean remuneration of the board (DispBoard) each of which is calculated for salary, cash compensation and total compensation. US_CEO is a dummy equal to one if a company is headed by CEO with American nationality and zero otherwise. BOARD_SIZE is the size of the board which is calculated as the total umber of executive and non-executive directors sitting on a board, BOARD_INDEP, is a ratio of the number of independent directors to the size of the board, INSIDER_OWNER is a fraction of shares held by insiders, INSTIT_OWNER is a fraction of outstanding shares held by financial institutions. Constant, industry and year dummy variables are included as controls but not reported. Firm-clustered standard errors are in parentheses. *** - significant at the $1 \%$ level, ** - significant at the $5 \%$ level and $*$-significant at the $10 \%$ level.

\begin{tabular}{|c|c|c|c|c|c|c|}
\hline \multirow[b]{2}{*}{ Panel A:ROE } & \multicolumn{2}{|c|}{ Salary } & \multicolumn{2}{|c|}{ Cash Compensation } & \multicolumn{2}{|c|}{ Total Compensation } \\
\hline & DispTop/FD & DipsBoard & DispTop/F & DipsBoard & DispTop/FD & DipsBoard \\
\hline $\ln ($ SALES) & $\begin{array}{c}0.049 * * * \\
(0.013)\end{array}$ & $\begin{array}{c}0.061 * * * \\
(0.012)\end{array}$ & $\begin{array}{c}0.049 * * * \\
(0.013)\end{array}$ & $\begin{array}{c}0.060 * * * \\
(0.012)\end{array}$ & $\begin{array}{c}0.049 * * * \\
(0.013)\end{array}$ & $\begin{array}{c}0.060 * * * \\
(0.012)\end{array}$ \\
\hline LEVERAGE & $\begin{array}{l}-0.104 \\
(0.219)\end{array}$ & $\begin{array}{l}-0.068 \\
(0.181)\end{array}$ & $\begin{array}{l}-0.088 \\
(0.219)\end{array}$ & $\begin{array}{l}-0.071 \\
(0.181)\end{array}$ & $\begin{array}{l}-0.082 \\
(0.220)\end{array}$ & $\begin{array}{l}-0.076 \\
(0.181)\end{array}$ \\
\hline BOARD_SIZE & $\begin{array}{l}-0.010 \\
(0.008)\end{array}$ & $\begin{array}{l}-0.011 \\
(0.007)\end{array}$ & $\begin{array}{l}-0.009 \\
(0.008)\end{array}$ & $\begin{array}{l}-0.010 \\
(0.007)\end{array}$ & $\begin{array}{l}-0.008 \\
(0.008)\end{array}$ & $\begin{array}{l}-0.011 \\
(0.007)\end{array}$ \\
\hline BOARD_INDEP & $\begin{array}{c}-0.479 * * \\
(0.212)\end{array}$ & $\begin{array}{c}-0.483 * * * \\
(0.180)\end{array}$ & $\begin{array}{c}-0.500 * * \\
(0.209)\end{array}$ & $\begin{array}{c}-0.493 * * * \\
(0.176)\end{array}$ & $\begin{array}{c}-0.509 * * \\
(0.207)\end{array}$ & $\begin{array}{c}-0.498 * * * \\
(0.175)\end{array}$ \\
\hline INSIDER_OWNER & $\begin{array}{l}-0.045 \\
(0.105)\end{array}$ & $\begin{array}{l}-0.014 \\
(0.103)\end{array}$ & $\begin{array}{l}-0.037 \\
(0.103)\end{array}$ & $\begin{array}{l}-0.013 \\
(0.103)\end{array}$ & $\begin{array}{l}-0.028 \\
(0.103)\end{array}$ & $\begin{array}{l}-0.008 \\
(0.103)\end{array}$ \\
\hline INSTIT_OWNER & $\begin{array}{l}-0.024 \\
(0.127)\end{array}$ & $\begin{array}{c}0.027 \\
(0.116)\end{array}$ & $\begin{array}{l}-0.017 \\
(0.126)\end{array}$ & $\begin{array}{c}0.041 \\
(0.116)\end{array}$ & $\begin{array}{l}-0.015 \\
(0.125)\end{array}$ & $\begin{array}{c}0.043 \\
(0.116)\end{array}$ \\
\hline US_CEO & $\begin{array}{l}-0.184 \\
(0.164)\end{array}$ & $\begin{array}{c}-0.194 * * \\
(0.095)\end{array}$ & $\begin{array}{c}-0.230 * * \\
(0.112)\end{array}$ & $\begin{array}{c}0.149 \\
(0.316)\end{array}$ & $\begin{array}{l}-0.131 \\
(0.117)\end{array}$ & $\begin{array}{c}0.361 \\
(0.307)\end{array}$ \\
\hline US_CEO x DISPERSION & $\begin{array}{c}0.135 \\
(0.105)\end{array}$ & $\begin{array}{l}0.567 * * \\
(0.250)\end{array}$ & $\begin{array}{c}0.151 * * \\
(0.064)\end{array}$ & $\begin{array}{l}-0.287 \\
(0.757)\end{array}$ & $\begin{array}{c}0.094 \\
(0.066)\end{array}$ & $\begin{array}{l}-0.726 \\
(0.663)\end{array}$ \\
\hline DISPERSION & $\begin{array}{l}-0.062 * \\
(0.036)\end{array}$ & $\begin{array}{l}-0.248^{*} \\
(0.145)\end{array}$ & $\begin{array}{l}-0.055 \\
(0.034)\end{array}$ & $\begin{array}{l}-0.187 \\
(0.121)\end{array}$ & $\begin{array}{l}-0.050 \\
(0.031)\end{array}$ & $\begin{array}{l}-0.082 \\
(0.088)\end{array}$ \\
\hline $\begin{array}{l}\text { Observations } \\
\text { AdjustedR2 }\end{array}$ & $\begin{array}{c}1,710 \\
0.07\end{array}$ & $\begin{array}{c}2,040 \\
0.07\end{array}$ & $\begin{array}{c}1,710 \\
0.07\end{array}$ & $\begin{array}{c}2,040 \\
0.07\end{array}$ & $\begin{array}{c}1,712 \\
0.07\end{array}$ & $\begin{array}{c}2,042 \\
0.07\end{array}$ \\
\hline Panel B: ROCE & & & & & & \\
\hline $\ln ($ SALES) & $\begin{array}{c}0.036 * * * \\
(0.005)\end{array}$ & $\begin{array}{c}0.036 * * * \\
(0.005)\end{array}$ & $\begin{array}{c}0.036 * * * \\
(0.005)\end{array}$ & $\begin{array}{c}0.036 * * * \\
(0.005)\end{array}$ & $\begin{array}{c}0.036 * * * \\
(0.005)\end{array}$ & $\begin{array}{c}0.036 * * * \\
(0.005)\end{array}$ \\
\hline LEVERAGE & $\begin{array}{c}-0.106^{* *} \\
(0.048)\end{array}$ & $\begin{array}{c}-0.086^{* *} \\
(0.041)\end{array}$ & $\begin{array}{c}-0.106^{* *} \\
(0.048)\end{array}$ & $\begin{array}{c}-0.088^{* *} \\
(0.041)\end{array}$ & $\begin{array}{c}-0.102 * * \\
(0.048)\end{array}$ & $\begin{array}{c}-0.088 * * \\
(0.041)\end{array}$ \\
\hline BOARD_SIZE & $\begin{array}{c}-0.009 * * * \\
(0.003)\end{array}$ & $\begin{array}{c}-0.008^{* * *} \\
(0.003)\end{array}$ & $\begin{array}{c}-0.009 * * * \\
(0.003)\end{array}$ & $\begin{array}{c}-0.008^{* * *} * \\
(0.003)\end{array}$ & $\begin{array}{c}-0.009 * * \\
(0.003)\end{array}$ & $\begin{array}{c}-0.008 * * * \\
(0.003)\end{array}$ \\
\hline BOARD_INDEP & $\begin{array}{c}-0.128^{* *} \\
(0.056)\end{array}$ & $\begin{array}{c}-0.138 * * * \\
(0.050)\end{array}$ & $\begin{array}{c}-0.136 * * \\
(0.058)\end{array}$ & $\begin{array}{c}-0.143^{* * *} \\
(0.052)\end{array}$ & $\begin{array}{c}-0.133 * * \\
(0.057)\end{array}$ & $\begin{array}{c}-0.144 * * * \\
(0.052)\end{array}$ \\
\hline INSIDER_OWNER & $\begin{array}{c}0.059 \\
(0.039)\end{array}$ & $\begin{array}{c}0.059 \\
(0.037)\end{array}$ & $\begin{array}{c}0.059 \\
(0.040)\end{array}$ & $\begin{array}{c}0.059 \\
(0.038)\end{array}$ & $\begin{array}{c}0.061 \\
(0.040)\end{array}$ & $\begin{array}{c}0.061 \\
(0.038)\end{array}$ \\
\hline INSTIT_OWNER & $\begin{array}{c}0.056 \\
(0.046)\end{array}$ & $\begin{array}{c}0.049 \\
(0.042)\end{array}$ & $\begin{array}{c}0.054 \\
(0.046)\end{array}$ & $\begin{array}{c}0.052 \\
(0.043)\end{array}$ & $\begin{array}{c}0.057 \\
(0.047)\end{array}$ & $\begin{array}{c}0.053 \\
(0.043)\end{array}$ \\
\hline US_CEO & $\begin{array}{l}-0.066 \\
(0.082)\end{array}$ & $\begin{array}{c}-0.113 * * \\
(0.052)\end{array}$ & $\begin{array}{l}-0.102 \\
(0.064)\end{array}$ & $\begin{array}{c}-0.084 * \\
(0.044)\end{array}$ & $\begin{array}{l}-0.081 \\
(0.070)\end{array}$ & $\begin{array}{l}-0.018 \\
(0.056)\end{array}$ \\
\hline US_CEO x DISPERSION & $\begin{array}{c}0.011 \\
(0.044)\end{array}$ & $\begin{array}{c}0.302 * * \\
(0.136)\end{array}$ & $\begin{array}{c}0.030 \\
(0.031)\end{array}$ & $\begin{array}{c}0.194 * * \\
(0.093)\end{array}$ & $\begin{array}{c}0.018 \\
(0.033)\end{array}$ & $\begin{array}{c}0.038 \\
(0.102)\end{array}$ \\
\hline DISPERSION & $\begin{array}{l}-0.011 \\
(0.009)\end{array}$ & $\begin{array}{c}-0.109 * * * \\
(0.037)\end{array}$ & $\begin{array}{c}0.000 \\
(0.007)\end{array}$ & $\begin{array}{l}-0.051 \\
(0.038)\end{array}$ & $\begin{array}{l}-0.008 \\
(0.006)\end{array}$ & $\begin{array}{l}-0.050 * \\
(0.030)\end{array}$ \\
\hline Observations & 1,669 & 1,988 & 1,669 & 1,988 & 1,671 & 1,990 \\
\hline AdjustedR2 & 0.20 & 0.22 & 0.20 & 0.22 & 0.20 & 0.22 \\
\hline
\end{tabular}




\begin{tabular}{|c|c|c|c|c|c|c|}
\hline \multicolumn{7}{|c|}{ Continuation of Table 8} \\
\hline \multicolumn{7}{|l|}{ Panel C: PM } \\
\hline \multirow[t]{2}{*}{$\ln ($ SALES $)$} & $0.013 * *$ & $0.015 * * *$ & $0.013 * *$ & $0.014 * *$ & $0.013 * *$ & $0.014 * *$ \\
\hline & $(0.006)$ & $(0.005)$ & $(0.006)$ & $(0.006)$ & $(0.006)$ & $(0.005)$ \\
\hline \multirow[t]{2}{*}{ LEVERAGE } & -0.007 & 0.004 & -0.007 & 0.002 & -0.005 & 0.003 \\
\hline & $(0.029)$ & $(0.028)$ & $(0.029)$ & $(0.028)$ & $(0.029)$ & $(0.028)$ \\
\hline \multirow[t]{2}{*}{ BOARD_SIZE } & -0.004 & $-0.004 *$ & -0.004 & $-0.004 *$ & -0.003 & $-0.004 *$ \\
\hline & $(0.002)$ & $(0.002)$ & $(0.002)$ & $(0.002)$ & $(0.002)$ & $(0.002)$ \\
\hline \multirow[t]{2}{*}{ BOARD_INDEPENDENCE } & $-0.106^{* *}$ & $-0.091 * *$ & $-0.111 * * *$ & $-0.092 * *$ & $-0.104 * *$ & $-0.089 * *$ \\
\hline & $(0.041)$ & $(0.040)$ & $(0.041)$ & $(0.040)$ & $(0.041)$ & $(0.040)$ \\
\hline \multirow[t]{2}{*}{ INSIDER_OWNER } & -0.023 & -0.025 & -0.023 & -0.026 & -0.021 & -0.024 \\
\hline & $(0.026)$ & $(0.025)$ & $(0.026)$ & $(0.025)$ & $(0.026)$ & $(0.025)$ \\
\hline \multirow[t]{2}{*}{ INSTIT_OWNER } & 0.024 & 0.023 & 0.022 & 0.026 & 0.026 & 0.029 \\
\hline & $(0.025)$ & $(0.026)$ & $(0.025)$ & $(0.026)$ & $(0.026)$ & $(0.026)$ \\
\hline \multirow[t]{2}{*}{ US_CEO } & $-0.155^{*}$ & $-0.164 * * *$ & $-0.174 * *$ & $-0.095 * *$ & -0.064 & 0.005 \\
\hline & $(0.091)$ & $(0.057)$ & $(0.073)$ & $(0.039)$ & $(0.095)$ & $(0.051)$ \\
\hline \multirow[t]{2}{*}{ US_CEO x DISPERSION } & 0.054 & $0.364 * * *$ & $0.059^{*}$ & 0.153 & -0.001 & -0.073 \\
\hline & $(0.047)$ & $(0.134)$ & $(0.035)$ & $(0.127)$ & $(0.055)$ & $(0.104)$ \\
\hline \multirow[t]{2}{*}{ DISPERSION } & -0.007 & $-0.059 * *$ & -0.000 & -0.016 & -0.002 & -0.014 \\
\hline & $(0.006)$ & $(0.029)$ & $(0.005)$ & $(0.026)$ & $(0.004)$ & $(0.020)$ \\
\hline Observations & 1,668 & 1,966 & 1,668 & 1,966 & 1,670 & 1,968 \\
\hline AdjustedR2 & 0.17 & 0.17 & 0.17 & 0.17 & 0.17 & 0.17 \\
\hline
\end{tabular}




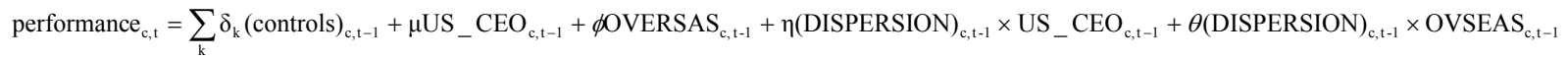
$+\lambda(\text { DISPERSION })_{\mathrm{c}, \mathrm{t}-1}+\varepsilon_{\mathrm{c}, \mathrm{t}}$

where performance is measured by the return on equity (ROE, Panel A), return on capital employed (ROCE, Panel B), and profit margin (PM, Panel C). For DISPERSION is either the ratio of the top executive's remuneration to the FD's remuneration (DispTop/FD) or the standard deviation of the remuneration of board executive members to the mean remuneration of the board (DispBoard) each of which is calculated for salary, cash compensation and total compensation. US_CEO is a dummy equal to one if a company is headed by CEO with American nationality and zero otherwise. OVSEAS is a dummy equal to 1 if the top manager's nationality is neither British nor American, and zero otherwise. BOARD_SIZE is the size of the board which is calculated as the total umber of executive and non-executive directors sitting on a board, BOARD_INDEP, is a ratio of the number of independent directors to the size of the board, INSIDER-OWNER is a fraction of shares held by insiders, INSTIT_OWNER is a fraction of outstanding shares held by financial institutions. Constant, industry and year dummy variables are included as controls but not reported. Firm-clustered standard errors are in parentheses. *** - significant at the $1 \%$ level, ** significant at the $5 \%$ level and $*$-significant at the $10 \%$ level.

\begin{tabular}{|c|c|c|c|c|c|c|}
\hline \multirow[b]{2}{*}{ Panel A:ROE } & \multicolumn{2}{|c|}{ Salary } & \multicolumn{2}{|c|}{ Cash Compensation } & \multicolumn{2}{|c|}{ Total Compensation } \\
\hline & DispTop/FD & DipsBoard & DispTop/F & DipsBoard & DispTop/FD & DipsBoard \\
\hline \multirow[t]{2}{*}{$\ln$ (SALES) } & $0.050 * * *$ & $0.061 * * *$ & $0.049 * * *$ & $0.060 * * *$ & $0.050 * * *$ & $0.060 * * *$ \\
\hline & $(0.013)$ & $(0.012)$ & $(0.013)$ & $(0.012)$ & $(0.013)$ & $(0.012)$ \\
\hline \multirow[t]{2}{*}{ LEVERAGE } & -0.107 & -0.071 & -0.090 & -0.073 & -0.084 & -0.079 \\
\hline & $(0.220)$ & $(0.181)$ & $(0.219)$ & $(0.181)$ & $(0.220)$ & $(0.181)$ \\
\hline \multirow[t]{2}{*}{ BOARD_SIZE } & -0.010 & $-0.011 *$ & -0.008 & -0.010 & -0.008 & -0.011 \\
\hline & $(0.008)$ & $(0.007)$ & $(0.008)$ & $(0.007)$ & $(0.008)$ & $(0.007)$ \\
\hline \multirow[t]{2}{*}{ BOARD_INDEP } & $-0.533 * *$ & $-0.530 * * *$ & $-0.556 * * *$ & $-0.543 * * *$ & $-0.565^{* * *}$ & $-0.547 * * *$ \\
\hline & $(0.214)$ & $(0.180)$ & $(0.211)$ & $(0.177)$ & $(0.208)$ & $(0.176)$ \\
\hline \multirow[t]{2}{*}{ INSIDER_OWNER } & -0.050 & -0.019 & -0.042 & -0.022 & -0.034 & -0.014 \\
\hline & $(0.106)$ & $(0.103)$ & $(0.104)$ & $(0.103)$ & $(0.104)$ & $(0.103)$ \\
\hline \multirow[t]{2}{*}{ INSTIT_OWNER } & -0.025 & 0.025 & -0.017 & 0.038 & -0.014 & 0.041 \\
\hline & $(0.127)$ & $(0.116)$ & $(0.126)$ & $(0.116)$ & $(0.125)$ & $(0.116)$ \\
\hline \multirow[t]{2}{*}{ US_CEO } & -0.204 & $-0.176^{*}$ & $-0.245 * *$ & 0.171 & -0.144 & 0.369 \\
\hline & $(0.162)$ & $(0.098)$ & $(0.111)$ & $(0.318)$ & $(0.118)$ & $(0.310)$ \\
\hline \multirow[t]{2}{*}{ OVSEAS } & -0.035 & 0.095 & -0.062 & -0.004 & -0.081 & 0.059 \\
\hline & $(0.108)$ & $(0.105)$ & $(0.098)$ & $(0.088)$ & $(0.100)$ & $(0.071)$ \\
\hline \multirow[t]{2}{*}{ US_CEOxDISPERSION } & 0.148 & $0.552 * *$ & $0.159 * *$ & -0.303 & 0.102 & -0.715 \\
\hline & $(0.048)$ & $(0.135)$ & $(0.035)$ & $(0.126)$ & $(0.055)$ & $(0.105)$ \\
\hline \multirow[t]{2}{*}{ OVSEASxDISPERSION } & 0.000 & -0.036 & -0.013 & -0.053 & -0.005 & -0.097 \\
\hline & $(0.013)$ & $(0.093)$ & $(0.015)$ & $(0.097)$ & $(0.009)$ & $(0.076)$ \\
\hline \multirow[t]{2}{*}{ DISPERSION } & -0.007 & $-0.057 *$ & 0.001 & -0.012 & -0.001 & -0.006 \\
\hline & $(0.007)$ & $(0.030)$ & $(0.005)$ & $(0.027)$ & $(0.004)$ & $(0.021)$ \\
\hline Observations & 1,668 & 1,966 & 1,668 & 1,966 & 1,670 & 1,968 \\
\hline AdjustedR2 & 0.18 & 0.19 & 0.18 & 0.19 & 0.18 & 0.19 \\
\hline \multicolumn{7}{|l|}{ Panel B: ROE } \\
\hline \multirow[t]{2}{*}{$\ln ($ SALES $)$} & $0.036 * * *$ & $0.036 * * *$ & $0.036 * * *$ & $0.036 * * *$ & $0.036 * * *$ & $0.036 * * *$ \\
\hline & $(0.005)$ & $(0.005)$ & $(0.005)$ & $(0.005)$ & $(0.005)$ & $(0.005)$ \\
\hline \multirow[t]{2}{*}{ LEVERAGE } & $-0.106 * *$ & $-0.087 * *$ & $-0.106 * *$ & $-0.089 * *$ & $-0.102 * *$ & $-0.089 * *$ \\
\hline & $(0.049)$ & $(0.041)$ & $(0.048)$ & $(0.042)$ & $(0.048)$ & $(0.041)$ \\
\hline \multirow[t]{2}{*}{ BOARD_SIZE } & $-0.009 * * *$ & $-0.008 * * *$ & $-0.009 * * *$ & $-0.008 * * *$ & $-0.009 * *$ & $-0.008 * * *$ \\
\hline & $(0.003)$ & $(0.003)$ & $(0.003)$ & $(0.003)$ & $(0.003)$ & $(0.003)$ \\
\hline \multirow[t]{2}{*}{ BOARD_INDEP } & $-0.128 * *$ & $-0.139 * * *$ & $-0.134 * *$ & $-0.144 * * *$ & $-0.132 * *$ & $-0.145 * * *$ \\
\hline & $(0.057)$ & $(0.050)$ & $(0.058)$ & $(0.052)$ & $(0.057)$ & $(0.051)$ \\
\hline INSIDER_OWNER & 0.058 & 0.059 & 0.059 & 0.058 & 0.061 & 0.062 \\
\hline & $(0.039)$ & $(0.037)$ & $(0.040)$ & $(0.038)$ & $(0.040)$ & $(0.038)$ \\
\hline INSTIT_OWNER & 0.056 & 0.049 & 0.054 & 0.051 & 0.057 & 0.053 \\
\hline & $(0.046)$ & $(0.042)$ & $(0.046)$ & $(0.043)$ & $(0.047)$ & $(0.043)$ \\
\hline US_CEO & -0.065 & $-0.109 * *$ & -0.101 & $-0.080 *$ & -0.077 & -0.012 \\
\hline & $(0.083)$ & $(0.053)$ & $(0.064)$ & $(0.045)$ & $(0.070)$ & $(0.057)$ \\
\hline OVSEAS & 0.011 & 0.020 & 0.029 & 0.009 & 0.027 & 0.049 \\
\hline & $(0.028)$ & $(0.045)$ & $(0.026)$ & $(0.048)$ & $(0.028)$ & $(0.035)$ \\
\hline US_CEOxDISPERSION & 0.011 & $0.299 * *$ & 0.029 & $0.191 * *$ & 0.017 & 0.030 \\
\hline & $(0.044)$ & $(0.137)$ & $(0.031)$ & $(0.095)$ & $(0.033)$ & $(0.104)$ \\
\hline OVSEASxDISPERSION & -0.005 & -0.011 & -0.016 & 0.012 & -0.011 & -0.075 \\
\hline & $(0.013)$ & $(0.092)$ & $(0.010)$ & $(0.093)$ & $(0.010)$ & $(0.060)$ \\
\hline DISPERSION & -0.010 & $-0.109 * * *$ & 0.001 & -0.052 & -0.007 & -0.045 \\
\hline & $(0.010)$ & $(0.039)$ & $(0.008)$ & $(0.040)$ & $(0.007)$ & $(0.032)$ \\
\hline Observations & 1,669 & 1,988 & 1,669 & 1,988 & 1,671 & 1,990 \\
\hline AdjustedR2 & 0.20 & 0.22 & 0.20 & 0.22 & 0.20 & 0.22 \\
\hline
\end{tabular}


Continuation of Table 9

\begin{tabular}{lcccccc} 
Panel C: PM & & & & & \\
& $0.014^{* *}$ & $0.015^{* * *}$ & $0.014^{* *}$ & $0.014^{* *}$ & $0.013^{* *}$ & $0.014^{* *}$ \\
ln(SALES) & $(0.006)$ & $(0.005)$ & $(0.006)$ & $(0.006)$ & $(0.006)$ & $(0.005)$ \\
LEVERAGE & -0.007 & 0.004 & -0.006 & 0.002 & -0.004 & 0.003 \\
& $(0.029)$ & $(0.028)$ & $(0.029)$ & $(0.028)$ & $(0.029)$ & $(0.028)$ \\
BOARD_SIZE & -0.003 & $-0.004^{*}$ & -0.004 & $-0.004^{*}$ & -0.003 & $-0.004^{*}$ \\
& $(0.002)$ & $(0.002)$ & $(0.002)$ & $(0.002)$ & $(0.002)$ & $(0.002)$ \\
BOARD_INDEP & $-0.102^{* *}$ & $-0.091^{* *}$ & $-0.105^{* *}$ & $-0.091^{* *}$ & $-0.100^{* *}$ & $-0.089^{* *}$ \\
& $(0.041)$ & $(0.039)$ & $(0.041)$ & $(0.039)$ & $(0.041)$ & $(0.039)$ \\
INSIDER_OWNER & -0.023 & -0.024 & -0.023 & -0.025 & -0.021 & -0.023 \\
& $(0.026)$ & $(0.025)$ & $(0.026)$ & $(0.025)$ & $(0.026)$ & $(0.025)$ \\
INSTIT_OWNER & 0.023 & 0.023 & 0.021 & 0.027 & 0.025 & 0.029 \\
& $(0.025)$ & $(0.026)$ & $(0.025)$ & $(0.026)$ & $(0.025)$ & $(0.026)$ \\
US_CEO & $-0.164^{*}$ & $-0.164 * * *$ & $-0.182^{* *}$ & $-0.094 * *$ & -0.069 & 0.009 \\
& $(0.092)$ & $(0.057)$ & $(0.075)$ & $(0.040)$ & $(0.096)$ & $(0.051)$ \\
OVSEAS & -0.028 & 0.011 & -0.006 & 0.018 & -0.017 & 0.041 \\
& $(0.033)$ & $(0.046)$ & $(0.035)$ & $(0.047)$ & $(0.031)$ & $(0.043)$ \\
US_CEOxDISPERSION & 0.056 & $0.361 * * *$ & $0.061 *$ & 0.150 & -0.001 & -0.085 \\
& $(0.048)$ & $(0.135)$ & $(0.035)$ & $(0.126)$ & $(0.055)$ & $(0.105)$ \\
OVSEASxDISPERSION & 0.000 & -0.036 & -0.013 & -0.053 & -0.005 & -0.097 \\
DISPERSION & $(0.013)$ & $(0.093)$ & $(0.015)$ & $(0.097)$ & $(0.009)$ & $(0.076)$ \\
Observations & -0.007 & $-0.057^{*}$ & 0.001 & -0.012 & -0.001 & -0.006 \\
AdjustedR2 & $(0.007)$ & $(0.030)$ & $(0.005)$ & $(0.027)$ & $(0.004)$ & $(0.021)$ \\
\hline & 1,668 & 1,966 & 1,668 & 1,966 & 1,670 & 1,968 \\
& 0.17 & 0.18 & 0.18 & 0.17 & 0.17 & 0.17 \\
\hline
\end{tabular}

